\title{
High-Density Lipoprotein: Structural and Functional Changes Under Uremic Conditions and the Therapeutic Consequences
}

\author{
Mirjam Schuchardt, Markus Tölle, and Markus van der Giet
}

\section{Contents}

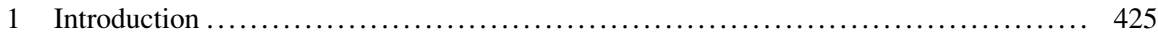

2 Chronic Kidney Disease: Epidemiology and Pathophysiology ................... 426

3 Dyslipidemia, Lipid-Modulating Therapy, and Cardiovascular Risk in CKD Patients . . 428

3.1 Dyslipidemia in CKD Patients ...................................... 428

3.2 Lipid-Modulating Therapy in CKD Patients ............................ 429

3.3 Protective Effects of HDL on the Kidney ............................ 434

4 Structural and Functional Modifications of HDL in CKD Patients .................. 436

4.1 Dysregulation of Proteins in HDL Metabolism ........................... 436

4.2 Changes of HDL Apolipoproteins (Modifications and Levels) .................. 438

4.3 Loss of Protective Proteins or Lipids ................................. 440

4.4 Increase of Molecules within HDL with a Fatal Function in the Vascular Wall ... 441

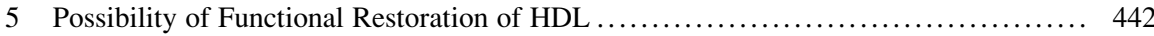

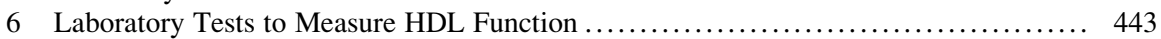

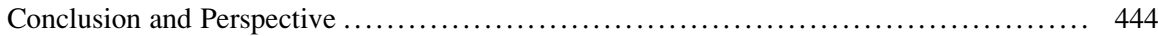

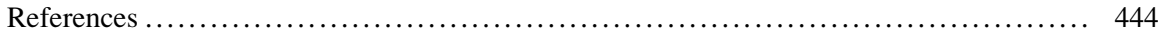

\section{Abstract}

High-density lipoprotein (HDL) has attracted interest as a therapeutic target in cardiovascular diseases in recent years. Although many functional mechanisms of the vascular protective effects of HDL have been identified, increasing the HDL plasma level has not been successful in all patient cohorts with increased cardiovascular risk. The composition of the HDL particle is very complex and

M. Schuchardt $\bullet$ M. Tölle

Department of Nephrology, Campus Benjamin Franklin, Charité - Universitaetsmedizin Berlin, Charité Centrum 13, Hindenburgdamm 30, 12203 Berlin, Germany

M. van der Giet $(\square)$

Department of Nephrology, Charité - Campus Benjamin Franklin, Hindenburgdamm 30, 12203

Berlin, Germany

e-mail: Markus.vanderGiet@charite.de

(C) The Author(s) 2015

A. von Eckardstein, D. Kardassis (eds.), High Density Lipoproteins, Handbook of

Experimental Pharmacology 224, DOI 10.1007/978-3-319-09665-0_13 
includes diverse lipids and proteins that can be modified in disease conditions. In patients with chronic kidney disease (CKD), the accumulation of uremic toxins, high oxidative stress, and chronic micro-inflammatory conditions contribute to changes in the HDL composition and may also account for protein/lipid modifications. These conditions are associated with a decreased protective function of HDL. Therefore, the HDL quantity and the functional quality of the particle must be considered.

This review summarizes the current knowledge of dyslipidemia in CKD patients, the effects of lipid-modulating therapy, and the structural modifications of HDL that are associated with dysfunction.

\section{Keywords}

Chronic kidney disease • Dyslipidemia • High-density lipoprotein • Uremia • Uremic toxin

\section{Abbreviations}

$\begin{array}{ll}\text { ABCA1 } & \text { ATP-binding cassette subfamily A } \\ \text { ADMA } & \text { Asymmetric dimethylarginine } \\ \text { AGE } & \text { Advanced glycated end product } \\ \text { AIM-HIGH } & \text { Atherothrombosis intervention in metabolic syndrome with low } \\ & \text { HDL/high triglycerides: impact on global health outcomes } \\ \text { ALERT } & \text { Assessment of LEscol in Renal Transplantation } \\ \text { apo } & \text { Apolipoprotein } \\ \text { AURORA } & \text { A study to evaluate the use of rosuvastatin in subjects on regular } \\ & \text { hemodialysis: an assessment of survival and cardiovascular events } \\ \text { CETP } & \text { Cholesterol ester transfer protein } \\ \text { CKD } & \text { Chronic kidney disease } \\ \text { cLDL } & \text { Carbamylated low-density lipoprotein } \\ \text { 4D } & \text { Deutsche Diabetes Dialyse Studie } \\ \text { DEFINE } & \text { Determining the Efficacy and Tolerability of CETP inhibition } \\ & \text { with Anacetrapib } \\ \text { DMA } & \text { Dimethylarginine } \\ \text { eGFR } & \text { Estimated glomerular filtration rate } \\ \text { EPIC } & \text { European Prospective Investigation into Cancer and Nutrition } \\ \text { ESRD } & \text { end-stage renal disease } \\ \text { GFR } & \text { Glomerular filtration rate } \\ \text { HD } & \text { Hemodialysis } \\ \text { HDL } & \text { High-density lipoprotein } \\ \text { HDL-C } & \text { High-density lipoprotein cholesterol } \\ \text { HMG-CoA } & \text { 3-hydroxy-3-methylglutaryl-coenzyme A } \\ \text { HPS2-THRIVE } & \text { Treatment of HDL to Reduce the Incidence of Vascular Events } \\ \text { IDL } & \text { Intermediate-density lipoprotein }\end{array}$


ILLUMINATE Investigation of Lipid Level Management to Understand Its Impact in Atherosclerotic Events

LCAT Lecithin-cholesterol acyltransferase

LDL Low-density lipoprotein

LDL-C Low-density lipoprotein cholesterol

Lp(a) Lipoprotein a

Lp-PLA Lipoprotein-associated phospholipase

LPL Lipoprotein lipase

MESA Multi-Ethnic Study of Atherosclerosis

MI Myocardial infarction

MPO Myeloperoxidase

NO Nitric oxide

n3-PUFA n3-polyunsaturated fatty acids

ox-apo Oxidized apolipoprotein

PAF-AH Platelet-activating factor acetylhydrolase

PD Peritoneal dialysis

PLA Phospholipase

PON Paraoxonase

PPAR Peroxisome proliferator-activated receptor

PREVEND-IT Prevention of Renal and Vascular End-Stage Disease Intervention Trial

RBP4 Retinol-binding protein 4

RCT Reverse cholesterol transport

RECORD Rosiglitazone evaluated for cardiovascular outcomes in oral agent combination therapy for type 2 diabetes

REVEAL Randomized evaluation of the effects of anacetrapib through lipid-modification

ROS Reactive oxygen species

SAA Serum amyloid A

SDMA Symmetric dimethylarginine

SHARP Study of Heart and Renal Protection

S1P Sphingosine-1-phosphate

sPLA2 Secretory phospholipase type 2

SR-BI Scavenger receptor BI

VA-HIT Veterans' Affairs High-Density Lipoprotein Intervention Trial

VLDL Very low-density lipoprotein

\section{$1 \quad$ Introduction}

Plasma lipoproteins are composed of non-covalent aggregates of different lipids and proteins. They transport water-insoluble substances in the blood by building micelle-like structures. These structures are classified by their density into the 
following groups: very low-density lipoprotein (VLDL), intermediate-density lipoprotein (IDL), low-density lipoprotein (LDL), and high-density lipoprotein (HDL).

In previous years, several clinical studies have found that HDL cholesterol (HDL-C) plasma levels were inversely correlated with cardiovascular risk, whereas high LDL-C levels were related to increased cardiovascular mortality (Di Angelantonio et al. 2009; Gordon et al. 1977; Mori et al. 1999). Initially, due to the crucial role of HDL in reverse cholesterol transport (RCT), HDL was associated with a decreased cardiovascular risk. Therefore, the theory of the "good HDL" and "bad LDL" emerged. Further studies, primarily in vitro or animal studies, identified the pleiotropic cardiovascular protective effects of HDL in addition to its RCT function: HDL has anti-atherosclerotic, anti-inflammatory, antioxidative, antithrombotic, and endothelial-protective properties (Navab et al. 2011). Accordingly, there is growing interest in the study of HDL metabolism and the cellular and the molecular signaling pathways involved in its vascular protective effects.

Therefore, enhancing HDL plasma levels has been a principal approach for the reduction of cardiovascular risks in different patient cohorts. Pharmacologically active substances, such as cholesterol ester transfer protein (CETP) inhibitors, fibrates, and niacin, have been tested in large clinical trials to evaluate the occurrence of cardiovascular endpoints (Longenecker et al. 2005; van Capelleveen et al. 2014). However, raising HDL-C plasma levels did not protect against cardiovascular events in all patient cohorts tested. In addition, despite a significant HDL-C increase in patients, large clinical trials were terminated because of a lack of positive effects or, in some cases, an increase in the rate of cardiovascular events.

These findings indicate that a better understanding of lipoprotein modifications in disease conditions is necessary to establish possible indications and target mechanisms in the therapy of cardiovascular diseases. Patients with chronic kidney disease (CKD) suffer from a dramatic increase in cardiovascular morbidity and mortality. The disease condition is associated with dyslipidemia and/or modifications in lipoprotein composition and function (Keane et al. 2013; Vaziri 2006).

This review summarizes current knowledge regarding the structural and functional changes of HDL in the context of renal dysfunction. A brief overview of CKD epidemiology and pathophysiology is presented, followed by aspects of dyslipidemia and its therapy in CKD patients. Subsequently, CKD-dependent structural and functional changes of HDL are summarized.

\section{Chronic Kidney Disease: Epidemiology and Pathophysiology}

Kidney disease is defined as an abnormality of kidney structure or function. The criteria for abnormalities include: albuminuria, urine sediment abnormalities, electrolyte and other abnormalities due to tubular disorders, abnormalities detected by 


\begin{tabular}{|c|c|c|}
\hline $\begin{array}{c}\text { eGFR } \\
{\left[\mathrm{mL} / \mathrm{min} / 1.73 \mathrm{~m}^{2}\right]}\end{array}$ & $\begin{array}{l}\text { CKD } \\
\text { caterogies }\end{array}$ & Description \\
\hline$\geq 90$ & I & Normal GFR, mildly to severely albuminuria \\
\hline $60-89$ & II & $\begin{array}{l}\text { Mildly decreases GFR, mildly to severely } \\
\text { albuminuria }\end{array}$ \\
\hline $45-59$ & IIla & $\begin{array}{l}\text { Moderately decreased GFR, mildly to severely } \\
\text { albuminuria }\end{array}$ \\
\hline $30-44$ & IIIb & $\begin{array}{l}\text { Moderately to severely decreased GFR, mildly } \\
\text { to severely albuminuria }\end{array}$ \\
\hline $15-29$ & IV & $\begin{array}{l}\text { Severely decreased GFR, mildly to severely } \\
\text { albuminuria }\end{array}$ \\
\hline$<15$ & V & $\begin{array}{l}\text { Kidney failure, mildly to severely albuminuria, } \\
\text { dialysis treatment }\end{array}$ \\
\hline
\end{tabular}

Fig. 1 Categories of chronic renal failure. CKD categories were divided into subgroups according to KDIGO 2013

histology or imaging, and history of kidney transplantation (Levey et al. 2005). Kidney disease can occur abruptly, and it can either resolve or become chronic. CKD is defined as kidney damage that persists for more than 3 months (Levey et al. 2005). CKD is one of the major medical concerns associated with premature morbidity and mortality, especially due to cardiovascular complications. The epidemic of CKD is globally driven by demographic aging, as well as an increase in other risk factors leading to $\mathrm{CKD}$ (e.g., diabetes mellitus, hypertension, and obesity).

CKD is divided into different stages, which are summarized in Fig. 1, based on the glomerular filtration rate (GFR) (Levey et al. 2005). CKD patients have a high occurrence of cardiovascular disease. In recent years, several studies have implicated an inverse correlation of kidney function and cardiovascular mortality (Tonelli et al. 2006). Thereby, the cardiovascular phenotype of the CKD population is heterogeneous, and the cardiovascular risk depends on the CKD stage. In addition to traditional risk factors, such as hypertension, diabetes mellitus, and smoking, nontraditional risk factors also contribute to cardiovascular diseases. In CKD patients, the nontraditional risk factors of anemia and enhanced oxidative stress or uremic toxins play a major role in cardiovascular disease progression (Mizobuchi et al. 2009). Under normal conditions, uremic toxins are cleared by the kidneys, and many of these toxins have been recently identified (Duranton et al. 2012). Uremic toxins are classified as water-soluble molecules with low molecular weight (e.g., uric acid), middle molecules (e.g., parathyroid hormone), and protein-bound toxins (e.g., hippuric acid) (Duranton et al. 2012). A number of different uremic toxins are elusive, and biological functions have not been identified for all toxins. Clinical studies have shown that cardiovascular morbidity and mortality in CKD patients are associated with uremic toxin accumulation, which leads to a progression of vascular alterations. Recently, Moradi et al. summarized the influence of uremic toxins on vascular cells and pathological pathways in the vascular wall (Moradi et al. 2013). The activation of leukocytes; 
endothelial damage, for example, by the disruption of glycocalyx and production of reactive oxygen species (ROS); the proliferating effects on smooth muscle cells; and platelet activation are only some of the described effects (Moradi et al. 2013). In addition, uremic toxins influence lipoprotein modifications. Urea induces the formation of carbamylated LDL (cLDL) (Apostolov et al. 2010). Some uremic toxins are lipid-bound and may occur in a different subfraction of lipoproteins. Additionally, HDL function may be affected by the accumulation of uremic toxins.

Nonetheless, further studies are necessary to characterize the impact of different compounds on cardiovascular outcome and the precise signaling pathways involved. The therapeutic goal should be to remove the solutes associated with the highest cardiovascular risk to minimize fatal cardiovascular outcomes in patients with CKD. To date, cardiovascular morbidity in patients with CKD remains high despite the utility of dialysis and renal transplantation (Foley et al. 1998).

\section{Dyslipidemia, Lipid-Modulating Therapy, and Cardiovascular Risk in CKD Patients}

In the general population, plasma lipid levels correlate with the level of cardiovascular risk (Di Angelantonio et al. 2009). Increased LDL-C levels have been associated with cardiovascular mortality. LDL-C is a primary risk biomarker for cardiovascular disease in the general population; however, it loses its prognostic association in CKD patients (Kilpatrick et al. 2007), especially for patients with end-stage renal disease (ESRD) (Baigent et al. 2011; Kovesdy et al. 2007). In addition, traditional risk factors, such as hypercholesterolemia, hypertension, and obesity, no longer appear to be related to the level of cardiovascular risk in ESRD patients. One explanation might be the accumulation of nontraditional risk factors in CKD patients (Appel 2004; Coresh et al. 1998; Muntner et al. 2004). Presumably, the complexity of traditional and nontraditional risk factors determines patient outcome. An alternative explanation may be that patient outcome is determined by the numerous quantitative and qualitative lipid abnormalities in triglycerides, phospholipids, and lipoproteins that are observed in CKD patient cohorts (Keane et al. 2013; Vaziri 2006).

\subsection{Dyslipidemia in CKD Patients}

Several studies have demonstrated a characteristic switch in the lipid phenotype at different stages of CKD. Data from the "Multi-Ethnic Study of Atherosclerosis" (MESA) have indicated an elevation of triglyceride-rich lipoproteins (LampreaMontealegre et al. 2013). Triglyceride-rich VLDL or other apoB-rich lipoproteins accumulate in patients with ESRD as a consequence of increased triglyceride levels (Vaziri and Norris 2011). The VLDL particle increase depends on the CKD stage and is aggravated by a decline in kidney function (Lamprea-Montealegre 
et al. 2013). Hypertriglyceridemia is caused by reduced lipoprotein lipase (LPL) levels (Vaziri 2006; Vaziri et al. 2012) and results in the limited delivery of triglyceride-rich fuel lipoproteins to adipocytes and myocytes (Vaziri et al. 2012). The enrichment of triglyceride-containing lipoprotein particles results in a higher susceptibility to oxidative modifications. These particles are highly pro-inflammatory (Vaziri 2013). In addition, other apoB-rich lipoproteins, such as small dense LDL or IDL-C, are commonly increased in patients with CKD (Saland and Ginsberg 2007; Vaziri 2006). The reduced clearance rate of LDL particles contributes to the increase in LDL levels (Ikewaki 2013).

Lipoprotein a ( $\operatorname{Lp}(\mathrm{a})$ ), which consists of apoA and apoB and is similar to LDL-C, is increased in CKD patients (Longenecker et al. 2005; Muntner et al. 2004). Lp (a) serves as an independent biomarker that predicts cardiovascular complications (Jacobson 2013; Thompson and Seed 2013).

Dyslipidemia is further enhanced by hyperparathyroidism, which frequently occurs in CKD patients (Moe and Sprague 2012). Normal lipid metabolism depends on proper parathyroid function, and hyperparathyroidism tends to result in hypertriglyceridemia (Liang et al. 1998) as well as in a deficiency in lipid metabolism enzymes, such as hepatic lipase and LPL (Klin et al. 1996). The enrichment of apoB-containing lipoproteins is correlated with decreased HDL-C levels (Saland and Ginsberg 2007; Vaziri 2006).

The lipid profile is altered in CKD patients compared with healthy subjects and differs depending on the stage of CKD progression (e.g., stage I to V, pre/postdialysis, and time on dialysis) and the dialysis procedure (e.g., hemodialysis (HD) or peritoneal dialysis (PD)). As a consequence, the lipid profiles of the CKD population are heterogeneous. Extrinsic factors, including drug administration for kidney disease and associated disorders (hypertension, diabetes mellitus, and malnutrition), contribute to dyslipidemia in this patient cohort.

To overcome the complex dyslipidemia in CKD patients, diverse clinical trials have addressed the influence of lipid-modulating therapies on cardiovascular outcomes. The results of these therapies in the general population suggest that the incidence of cardiovascular events in CKD patients is expected to decrease (van Capelleveen et al. 2014).

\subsection{Lipid-Modulating Therapy in CKD Patients}

Currently, drugs that treat dyslipidemia are in use or under investigation. Statins, which primarily lower the LDL-C level; peroxisome proliferator-activated receptor (PPAR) agonists; inhibitors of lipid metabolism (CETP, niacin); and apoAI mimetics have been evaluated in preclinical and/or clinical studies. The currently established lipidemic drugs have been reviewed elsewhere; therefore, this article summarizes aspects of therapy related to CKD. Although lipid-modulating therapies have had a positive impact on the cardiovascular outcome in patients with normal kidney function, the effect in CKD patients has been disappointing. These observations have originated predominantly from statin trials. 
Statin treatment leads to a reduction in LDL-C through the inhibition of 3-hydroxy-3-methylglutaryl-coenzyme A (HMG-CoA) reductase, the initial enzyme in endogenous cholesterol biosynthesis. In several clinical trials, it has been clearly demonstrated that for patients without renal disease, a reduction of LDL-C upon statin therapy is associated with a decreased cardiovascular mortality rate (The Long-Term Intervention with Pravastatin in Ischaemic Disease (LIPID) Study Group 1998; Scandinavian Simvastatin Survival Study Group 1994; Baigent et al. 2005; Collins et al. 2003; LaRosa et al. 2005; Sever et al. 2003). Due to the substantially high cardiovascular risk in CKD patients, the effect of statin therapy was also evaluated in three large clinical trials $(>1,000$ patients included): the "Deutsche Diabetes Dialyse Studie" (4D) (Wanner et al. 2005), "A Study to Evaluate the Use of Rosuvastatin in Subjects on Regular Hemodialysis: An Assessment of Survival and Cardiovascular Events" (AURORA) (Fellstrom et al. 2009a), and "Study of Heart and Renal Protection" (SHARP) (Baigent et al. 2011). The "Prevention of Renal and Vascular End-Stage Disease Intervention Trial" (PREVEND-IT) (Asselbergs et al. 2004; Brouwers et al. 2011) has also addressed the effect of statin therapy in a smaller cohort $(<1,000$ patients) but included a longer follow-up period. The "Assessment of LEscol in Renal Transplantation" (ALERT) (Holdaas et al. 2003) trial investigated cardiovascular outcomes in renal transplant recipients. The 4D study consisted of a randomized control trial that examined Western HD patients with diabetes (Wanner et al. 2005). No benefits in the primary endpoints were observed in a follow-up period of approximately 4 years (Wanner et al. 2005) (Table 1). A subsequent subgroup analysis of the 4D study cohort showed a reduction in cardiovascular disease after statin treatment in patients with LDL-C $>145 \mathrm{mg} / \mathrm{dL}$ (Marz et al. 2011). The 4D trial with 1,225 patients was followed by the larger AURORA trial, which enrolled 2,776 HD patients with and without diabetes mellitus. Nonetheless, the reduction in LDL-C that was observed did not have an effect on cardiovascular outcomes (Fellstrom et al. 2009a). Another large randomized trial, the SHARP trial, enrolled HD patients and CKD patients in stages III to V: (Baigent et al. 2011). The combination therapy of simvastatin and ezetimibe lowered the LDL-C level but did not reduce the overall vascular mortality (Baigent et al. 2011). However, the risk for atherosclerotic events was reduced in a wide range of CKD patients (Baigent et al. 2011). The longest follow-up period, up to 9.5 years, was in the PREVEND-IT trial (Asselbergs et al. 2004; Brouwers et al. 2011). Here, patients with microalbuminuria were enrolled and treated with pravastatin and fosinopril. In the follow-up period of 46 months, pravastatin treatment had no effect on cardiovascular endpoints (Asselbergs et al. 2004). The extended follow-up period of 9.5 years showed that elevated urinary albumin excretion was associated with increased cardiovascular morbidity and mortality (Brouwers et al. 2011).

Thus, the large clinical trials examining statin therapy in CKD patients failed to show a significant reduction in overall cardiovascular mortality for patients undergoing dialysis treatment (Table 1). Based on the data from the US Renal Data System, the majority of cardiovascular deaths in CKD patients are due to chronic heart failure and are not influenced by statin treatment (Collins et al. 2013). 


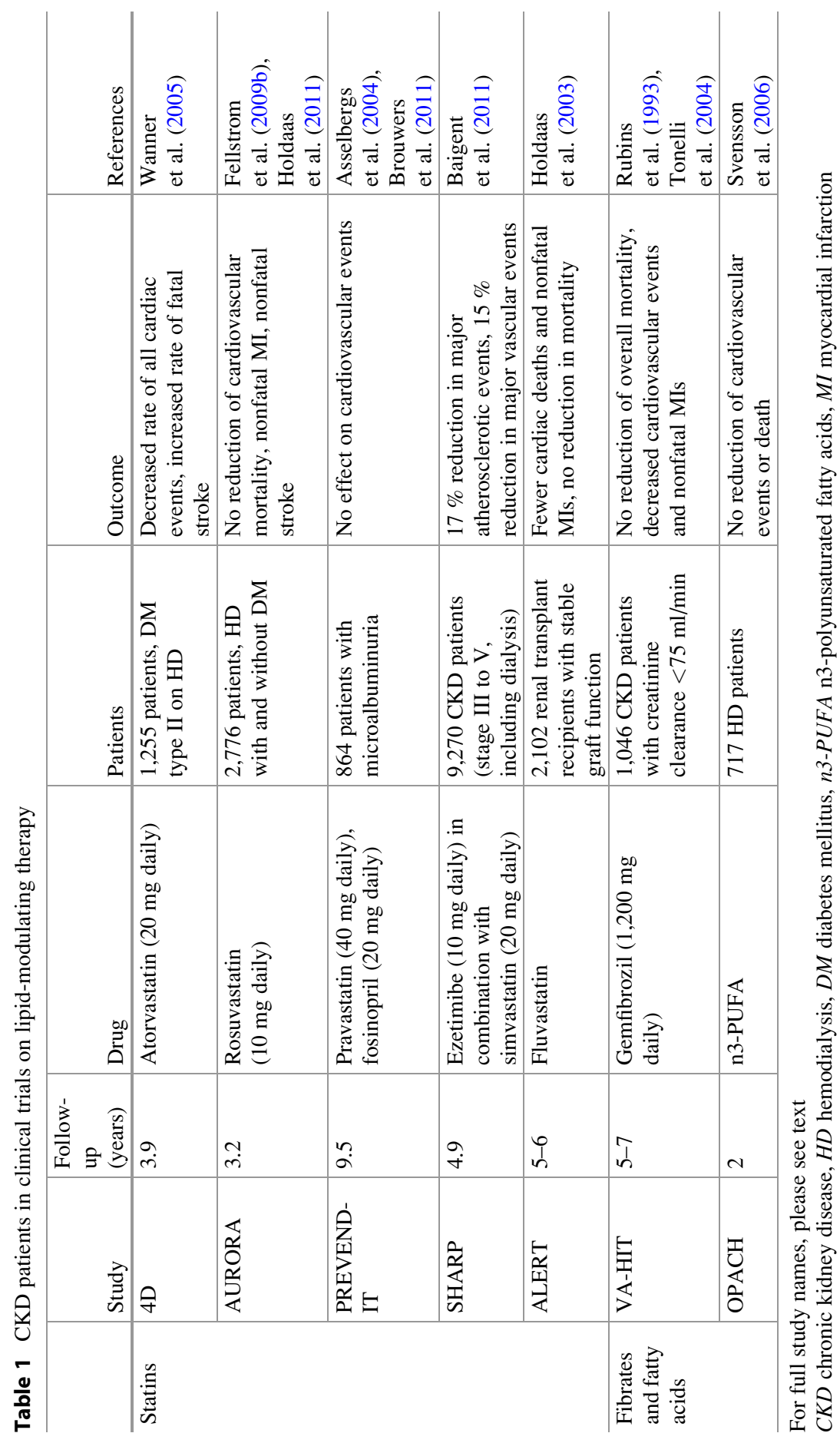


Therefore, other uremia-related pathways and/or the previously existing vascular damage may contribute to the increase in cardiovascular risk. A trial that investigated the effect of statin therapy in renal transplant recipients observed similar effects. In the ALERT trial (Holdaas et al. 2003), statin therapy reduced the LDL-C plasma concentration in treated patients (Holdaas et al. 2003). Although fewer cardiac deaths and nonfatal MIs were observed, no significant reduction in the primary endpoint was achieved (Holdaas et al. 2003).

Based on the findings of the current clinical trials with CKD patients, the therapies tested had either no real impact on cardiovascular outcome or resulted in fatal effects (Kilpatrick et al. 2007). Interestingly, despite a robust reduction in the LDL-C level, only negative or neutral effects on acute cardiovascular events were measured (Baigent et al. 2011; Fellstrom et al. 2009b; Wanner et al. 2005). Effective prevention of cardiovascular events was only documented in patients with mild to moderate CKD (Baigent et al. 2011).

In addition to statins, which primarily lower LDL-C plasma levels, other lipidmodulating drugs are currently used in non-renal-insufficient patients. Here, different targets in HDL metabolism have been identified to overcome dyslipidemia. Initial studies addressed the effect of enzyme inhibition on lipid metabolism, such as CETP inhibition. PPAR agonists, niacin, and apoAI mimetics are other therapeutic options that have been tested in clinical and/or preclinical studies. However, these studies often excluded patients with CKD from recruitment. Therefore, further studies are necessary to determine the effects of these therapies on patients with renal insufficiency.

CETP is responsible for the shuttling of cholesteryl esters between HDL and apoB-containing lipoprotein particles. Inhibition of this enzyme results in a dramatic increase in HDL levels. Torcetrapib was the first CETP inhibitor examined in a large clinical trial, "Investigation of Lipid Level Management to Understand Its Impact in Atherosclerotic Events" (ILLUMINATE) which included approximately 15,000 patients (Barter et al. 2007). The treatment increased the HDL concentration by more than $50 \%$ (Barter et al. 2007). However, the study was prematurely terminated because an increased risk of cardiovascular events was observed (e.g., increase in arterial blood pressure) (Barter et al. 2007). In the ILLUMINATE trial, patients with severe CKD were not enrolled. The mean eGFR in patients included in the study was $79.5 \mathrm{ml} / \mathrm{min} / 1.73 \mathrm{~m}^{2}$ with creatinine concentration of $1 \mathrm{mg} / \mathrm{dL}$ (Barter et al. 2007). In subsequent trials with other CETP inhibitors, which attempted to overcome the off-target effects of torcetrapib, CKD patients were excluded. The "Determining the Efficacy and Tolerability of CETP Inhibition with Anacetrapib" (DEFINE) study (Cannon et al. 2010) investigated anacetrapib, and a key exclusion criteria in this study was an eGFR $<30 \mathrm{ml} / \mathrm{min} / 1.73 \mathrm{~m}^{2}$ or severe renal impairment (Cannon et al. 2010). In the dal-OUTCOMES trial with dalcetrapib (Schwartz et al. 2009, 2012), the exclusion criteria was a creatinine level of $>2.2 \mathrm{mg} / \mathrm{dL}$ (Schwartz et al. 2009). For the "Randomized Evaluation of the Effects of Anacetrapib Through Lipid-Modification" (REVEAL) study, patient recruitment is ongoing, and the study is expected to be completed in 2017 (Gutstein et al. 2012). On the basis of the current CETP inhibitor studies, the effects of CETP 
inhibition on cardiovascular mortality cannot be determined, and patients with severe CKD were excluded from all studies.

Niacin treatment most effectively raises HDL-C levels and decreases triglyceride, LDL-C, and Lp(a) levels. The mechanism underlying the influence of niacin on HDL metabolism is unknown (Linsel-Nitschke and Tall 2005). The beneficial effects on lipoprotein levels and the corresponding cardiovascular outcome have been described in several small-scale clinical trials. Unfortunately, the large-scale trials AIM-HIGH (AIM-HIGH Investigators 2011; Boden et al. 2011) and HPS2THRIVE (2013), in which patients were treated with niacin in combination with a statin, were prematurely terminated because of a high prevalence of side effects. In both studies, no patients with severe CKD were included. In AIM-HIGH, the mean eGFR was $82.8 \mathrm{ml} / \mathrm{min} / 1.72 \mathrm{~m}^{2}$ (2011), and in HPS2-THRIVE, severe renal insufficiency was an exclusion criteria for patient recruitment (2013).

The family of PPAR transcription factors is involved in the regulation of fatty acid metabolism and influences lipid levels. The family consists of three members: PPAR- $\alpha$, PPAR $-\gamma$, and PPAR- $\delta$. PPAR- $\gamma$ agonists, such as rosiglitazone and pioglitazone, are high-affinity agonists at the receptor site (Linsel-Nitschke and Tall 2005), and their effects on cardiovascular outcome have been tested. However, only a minimal benefit or an increase in heart failure rates was observed in a study population with diabetes in the "Rosiglitazone Evaluated for Cardiovascular Outcomes in Oral Agent Combination Therapy for Type 2 Diabetes" (RECORD) trial (Home et al. 2009). The mean serum creatinine level in the study cohort was approximately $62 \mu \mathrm{mol} / \mathrm{L}$ (Home et al. 2009). The activation of PPAR- $\alpha$ via fibrates, which are weak agonists of this receptor (Linsel-Nitschke and Tall 2005), results in reductions in LDL-C and triglycerides, whereas HDL-C plasma levels are moderately increased (Linsel-Nitschke and Tall 2005; Sahebkar et al. 2014). The "Veterans' Affairs High-Density Lipoprotein Intervention Trial" (VA-HIT) (Tonelli et al. 2004) investigated the effects of the fibrate gemfibrozil in a cohort of individuals with CKD. Gemfibrozil treatment did not reduce overall mortality, but the rate of major cardiovascular events and nonfatal myocardial infarctions (MIs) was significantly reduced in patients with mild to moderate CKD (Tonelli et al. 2004). Currently, there are no synthetic ligands for PPAR- $\delta$ in clinical use (Sahebkar et al. 2014).

In the secondary prevention of cardiovascular disease, there is evidence that n3-polyunsaturated fatty acids (n3-PUFAs) are effective (Studer et al. 2005). A study with HD patients failed to show a reduction in cardiovascular events or death after treatment with an n3-PUFA (Svensson et al. 2006). However, a significant reduction of MIs was observed in this patient cohort (Svensson et al. 2006).

Additional pharmacotherapeutic strategies are currently under development. apoAI-based drugs and reconstituted/engineered HDL particles have been tested in animal and human studies. Recently, van Capelleveen et al. summarized current knowledge of these novel therapeutics (van Capelleveen et al. 2014). The human trials were completed with a limited patient number $(<200$ patients $)$ and a short follow-up period (several weeks). However, the clinical impact of these novel drugs is highly interesting and must be evaluated in larger clinical trials. Several trials are 
currently under way (van Capelleveen et al. 2014); however, the high treatment costs may limit their use in routine clinical practice. After the promising results in animal studies, treatment with apoAI mimetics did not improve biomarkers that were selected to describe HDL function (Watson et al. 2011).

To date, the benefit of apoAI-based therapy for CKD patients remains elusive.

The studies described indicate that with a decline in renal function, lipidmodulating therapies lose their capacity to prevent the occurrence of cardiovascular nonfatal and fatal events. Consequently, the lipid compositional and corresponding functional changes that occur with declining renal function are not fully understood. In Table 1, the different therapeutic approaches in patients with variable renal function and the effects on cardiovascular outcome are summarized.

Recent guidelines for the management of lipid disorders in patients with chronic renal failure recommend lipid-lowering therapy only in patients with CKD who are not undergoing renal replacement therapy (National Kidney Foundation 2003; Tonelli and Wanner 2013). The guidelines clearly indicate our inadequate understanding of how to address the complex lipid changes in CKD patients.

\subsection{Protective Effects of HDL on the Kidney}

Based on the current evidence, the causal association between the HDL level, HDL function, and cardiovascular outcome in CKD patients is not fully understood. Dysregulated HDL metabolism might be caused by reduced kidney function. Abnormalities in lipid metabolism enzymes and transport processes have been described (Hirano 2013; Pahl et al. 2009; Vaziri and Norris 2011). The changes involve enrichment of free cholesterol, triglycerides, and fatty acids as well as the depletion of cholesterol esters within HDL. However, there is evidence that HDL might be an independent protective factor for kidney function. Epidemiologic data from a multi-study cohort demonstrated an association between a low HDL-C level and reduced kidney function (Odden et al. 2013). Additional trials addressed the question of whether HDL-C is associated with the progression of CKD. A recent study, which included 3,303 patients with CKD stages III to V and a median followup period of 2.8 years, supports the hypothesis that dyslipidemia is independently associated with rapid renal progression (Chen et al. 2013). Two meta-analyses suggest that statin therapy has a benefit on GFR and inhibits GFR decline (Fried et al. 2001; Sandhu et al. 2006). However, other studies found no impact on renal outcome with statin treatment (Atthobari et al. 2006; Rahman et al. 2008). Focusing on HDL-C, Baragetti and coworkers observed an association between low HDL-C and earlier entry in dialysis or doubling of the plasma creatinine in a patient cohort of 176 subjects with mild to moderate kidney dysfunction (Baragetti et al. 2013). Moreover, a cross-sectional analysis of 4,925 patients with normal kidney function strengthened the association between HDL-C and eGFR (Wang et al. 2013). Confounders (e.g., age, blood pressure, and lipid parameters) influenced the relationship (Wang et al. 2013). Furthermore, malnutrition and hypoalbuminemia, 


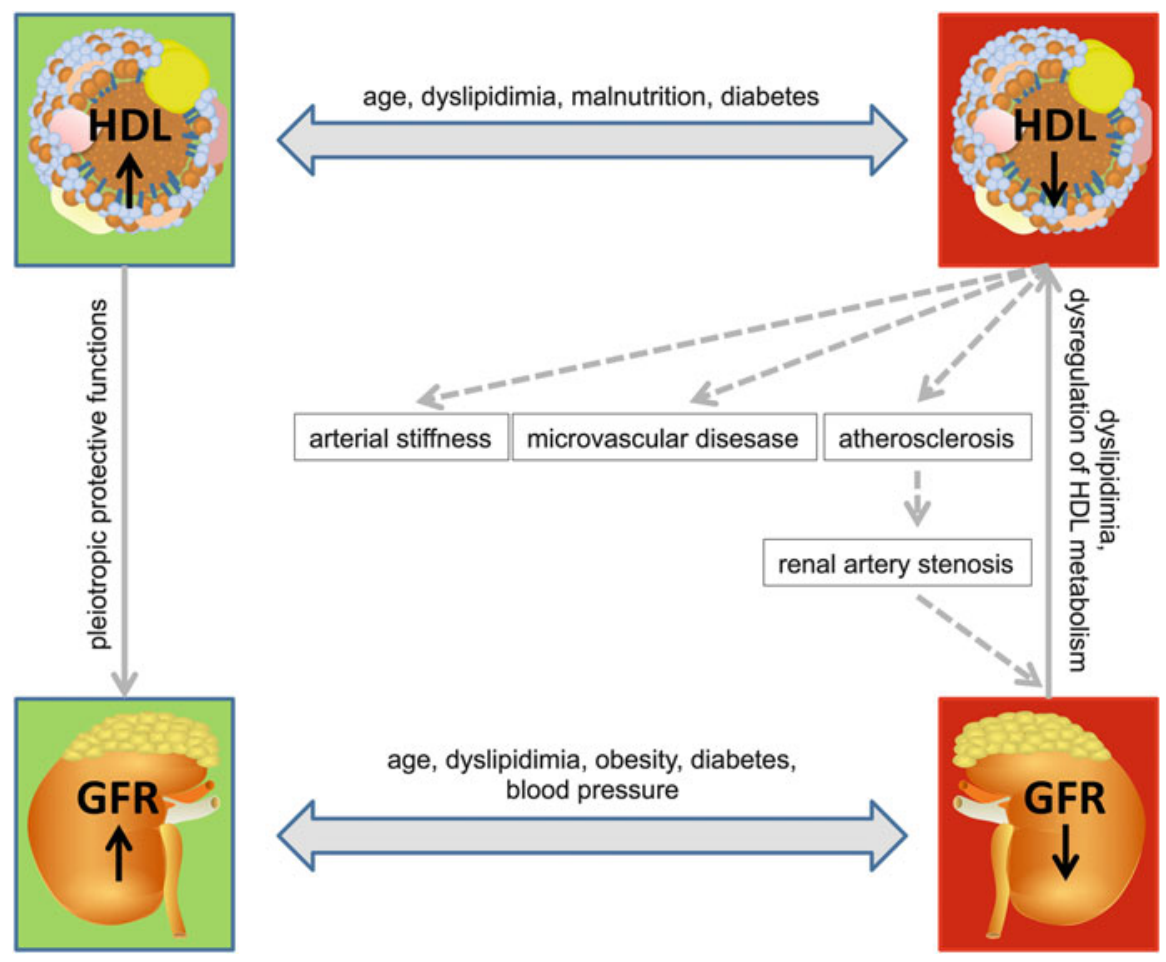

Fig. 2 Interaction of HDL level/function with the kidney. HDL has a pleiotropic protective function. A decrease in HDL level/function has an impact on the vascular alterations associated with kidney damage. The decline in kidney function induces/strengthens the decrease in HDL level/function. For further information and references, refer to the text

which are frequently present in patients with CKD (Kaysen 2009; Peev et al. 2014), affected the HDL level and functionality (Khovidhunkit et al. 2004).

Further studies are necessary to determine whether HDL-targeted therapies are beneficial for renal outcome. The difference in the HDL quantity and functional quality in CKD patients must be considered. The results of clinical trials, such as ILLUMINATE (Barter et al. 2007) and HPS2-THRIVE (2013), suggest that increasing HDL-C plasma levels is not an optimal therapeutic target. Furthermore, as shown in the "European Prospective Investigation into Cancer and Nutrition" (EPIC) study and the MESA study, intima/media thickness and cardiovascular events had a stronger association with HDL particle number compared with HDL cholesterol levels (Arsenault et al. 2009; El Harchaoui et al. 2009; Mackey et al. 2012). Figure 2 summarizes the potential protective effects of HDL on kidney function.

Additional studies that address the structure-dependent functions of the heterogeneous HDL particles are necessary to assess the benefit of HDL-increasing therapy for different disease conditions. 


\section{$4 \quad$ Structural and Functional Modifications of HDL in CKD Patients}

In the last several years, HDL and its structural composition in disease conditions, especially cardiovascular, metabolic, and renal diseases, have been a focus of experimental research. Compositional changes of the proteome, alterations of the lipid moiety, and posttranslational modifications of HDL isolated from these patient cohorts contribute to a lower protective function of the lipoprotein particle (Annema and von Eckardstein 2013). The following section summarizes the current knowledge of the HDL changes identified in patients with reduced renal function. It is important to keep in mind that the investigations were performed in a heterogeneous group of patients with different stages of renal failure. Therefore, it is often difficult to define the role of uremia on the functionality of HDL.

The HDL particle contains hundreds of different lipids and a multitude of proteins that form a lipoprotein with different shapes, sizes, and densities throughout its metabolism (Camont et al. 2011; Shah et al. 2013). Because of its amphiphilic character and the presence of specific binding proteins, HDL serves as cargo for vitamins, hormones, toxins, and microRNA (Vickers and Remaley 2014). There is evidence of biological activity for many of the lipid and protein components. These components can bind to specific receptors and activate signaling pathways in vascular cells, thereby influencing atherogenesis, thrombosis, apoptosis, oxidative reactions, endothelial properties, and inflammatory reactions (Calabresi et al. 2003; Navab et al. 1991; Nofer et al. 2004; Watson et al. 1995). The functions of the associated proteins and lipids in the vascular wall have been characterized in vitro and in animal studies, as well as in clinical trials. It has been shown that compositional changes are related to functionality and are influenced by uremic toxins. For example, (1) the dysregulation of proteins in the HDL metabolism affects HDL plasma level and cholesterol clearance. Furthermore, (2) changes in HDL apolipoprotein composition occur, and finally (3) the loss of proteins with a protective function or (4) the accumulation of substances with a fatal function within HDL influences its vascular protective properties. The compositional changes may not only result in a decrease in function but may also lead to increased dysfunction (Fig. 3), and both are associated with an increased cardiovascular risk profile.

\subsection{Dysregulation of Proteins in HDL Metabolism}

As discussed in the preceding paragraph, CKD is associated with a decreased HDL-C plasma concentration and dyslipidemia. The uremic condition is responsible for the disrupted protein metabolism (Vaziri 2006) due to uremic-induced liver damage (Yeung et al. 2013). Many proteins important in HDL metabolism are predominantly produced within the liver, and their production is dysregulated in uremia. For proper HDL maturation and metabolism, enzymes such as LCAT and CETP are responsible. Furthermore, diverse receptors on intestinal and peripheral cells, as well as hepatic cells, are necessary for cholesterol transport via HDL to the 


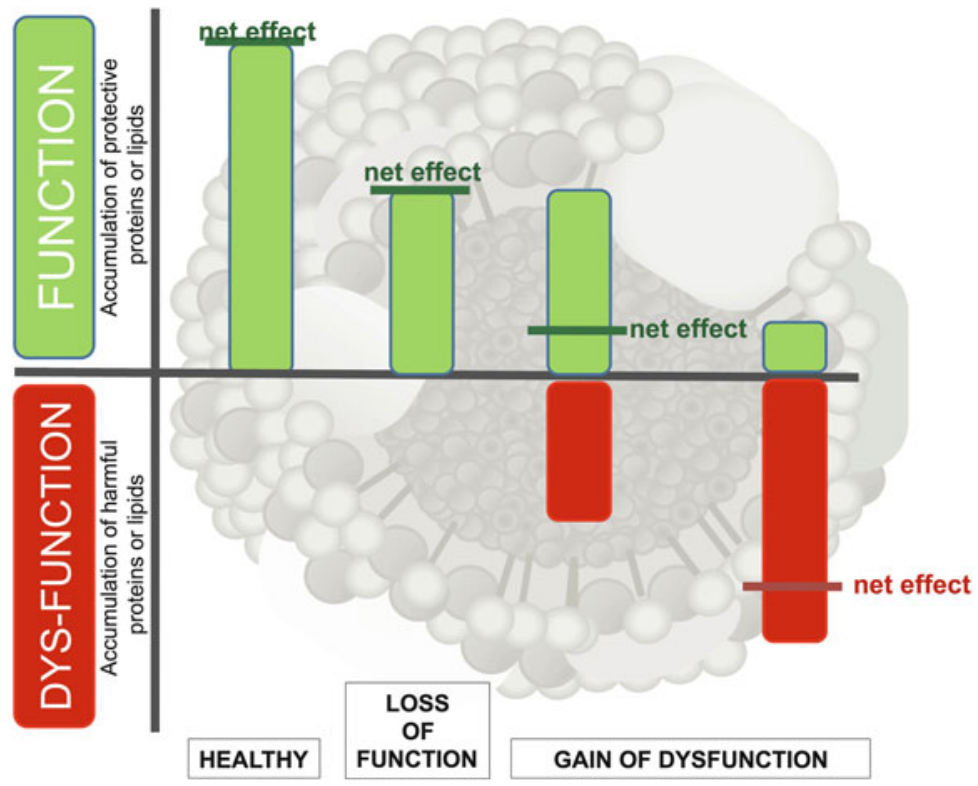

Fig. 3 Functional vs. dysfunctional HDL particles. Depending on the substances that accumulate within the HDL, the particle may exert functional or dysfunctional properties

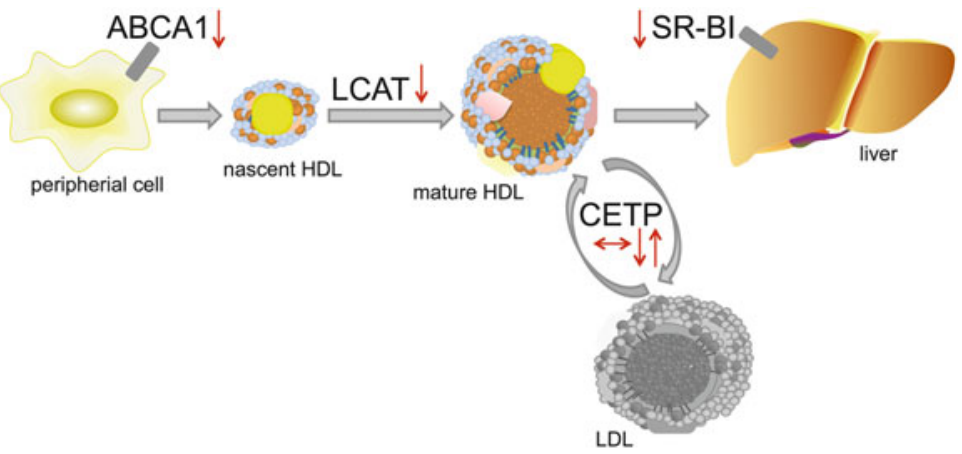

Fig. 4 Dysregulation in HDL metabolism under uremic conditions. $\downarrow$ decrease, $\uparrow$ increase, $\leftrightarrow$ no effect. For references, refer to the text

liver for biliary excretion (Fig. 4). There is evidence that the expression of enzymes and receptors in HDL metabolism is altered in patients who suffer from kidney disease. To date, most studies have been completed with CKD stage $\mathrm{V}$ patients dependent on dialysis (ESRD), and less information on enzyme expression has been obtained from patients prior to dialysis. LCAT is important for HDL maturation. In ESRD patients, the LCAT enzyme concentration and activity were reduced (Miida et al. 2003; Moradi et al. 2009; Pahl et al. 2009; Shoji et al. 1992; Tolle et al. 2012). 
The association between the plasma levels of cholesterol transport proteins, such as CETP and CKD, remains unclear. Some studies have failed to show any significant changes in the CETP protein level or activity (Pahl et al. 2009), whereas other studies have identified an increased (Dullaart et al. 1993) or decreased (Miida et al. 2003) CETP level. These controversial data may result from the heterogeneity of CKD patients and the analysis of different patient subgroups: increased levels were identified in proteinuric patients (Dullaart et al. 1993), and unchanged or decreased levels were identified in HD patients with different lengths of minimum dialysis treatment (minimum of 3 months vs. 1 year) (Miida et al. 2003; Pahl et al. 2009). The expression of receptors important for RCT appears to be affected by kidney dysfunction. In nephrectomy animal models, SR-BI (Liang and Vaziri 1999) and ABCA1 (Zuo et al. 2009) receptor expression is decreased. A reduction of these receptors in humans would subsequently be associated with altered HDL metabolism in CKD patients.

\subsection{Changes of HDL Apolipoproteins (Modifications and Levels)}

HDL contains different apolipoproteins. Under uremic conditions, the composition of the proteins within HDL changes: some protein levels decrease, whereas other protein levels increase. The main apolipoprotein of HDL under normal physiological conditions is apoAI. The presence of altered apoAI levels in CKD patients remains controversial. Some studies have identified decreased apoAI levels in dialysis patients (Holzer et al. 2011a; Moradi et al. 2009; Vaziri et al. 1999, 2009), whereas other studies did not identify a significant change in apoAI concentration (Shoji et al. 1992; Tolle et al. 2012). While apoAII and apoCI levels decreased in CKD patients (Holzer et al. 2011a), apoCII (Holzer et al. 2011a; Weichhart et al. 2012) and apoCIII (Holzer et al. 2011a) increased. ApoAIV was not identified in the HDL obtained from healthy subjects, but was detected in dialysis patients via mass spectrometry analysis (Holzer et al. 2011a). No significant difference was found in apoD and apoE levels, whereas apoM levels decreased (Holzer et al. 2011a). Table 2 summarizes the main apolipoprotein changes in CKD patients. Currently, most identified changes are based on studies with HD patients. The discrepancy in apolipoprotein levels may be a result of the heterogeneous patient population (e.g., CKD stage, time on dialysis, medication, or secondary disease), different HDL isolation protocols (e.g., one-step vs. multistep ultracentrifugation, chromatography, or differentiation between HDL2/3), and different apolipoprotein detection methods (e.g., enzyme-linked immunosorbent assay vs. mass spectrometry).

In addition to changes in the apolipoprotein levels, modifications of the proteins within HDL occurred, which were closely connected to altered functionality. To date, oxidative modifications, carbamylation, and glycosylation have been detected. These effects may be a consequence of the high level of ROS in patients with renal failure. 
Table 2 Differences in apolipoprotein composition within the HDL in CKD patients compared with healthy control subjects ( $\uparrow$ increase, $\downarrow$ decrease, $\leftrightarrow$ no change vs. healthy control)

\begin{tabular}{l|l|l}
\hline Apolipoprotein & $\begin{array}{l}\text { Change in the HDL } \\
\text { in CKD patients }\end{array}$ & References \\
\hline apoAI & $\downarrow \leftrightarrow$ & $\begin{array}{l}\text { Holzer et al. (2011a), Moradi et al. (2009), Shoji } \\
\text { et al. (1992), Tolle et al. (2012), Vaziri et al. (1999), } \\
\text { Vaziri et al. (2009) }\end{array}$ \\
\hline apoAII & $\downarrow$ & Holzer et al. (2011a) \\
\hline apoAIV & $\uparrow$ & Holzer et al. (2011a) \\
\hline apoCI & $\downarrow$ & Holzer et al. (2011a) \\
\hline apoCII & $\uparrow$ & Holzer et al. (2011a), Weichhart et al. (2012) \\
\hline apoCIII & $\uparrow$ & Holzer et al. (2011a) \\
\hline apoD & $\leftrightarrow$ & Holzer et al. (2011a) \\
\hline apoE & $\leftrightarrow$ & Holzer et al. (2011a) \\
\hline apoM & $\downarrow$ & Holzer et al. (2011a) \\
\hline
\end{tabular}

Patients with CKD suffer from increased reactive oxygen stress (Sung et al. 2013; Tucker et al. 2013). The pro-oxidant state is multifactorial but is related to high amounts of uremic toxins. Uremic toxins are directly involved in the oxidative response, e.g., phenyl acetic acid is a strong inducer of ROS (Schmidt et al. 2008), and indoxyl sulfate has a dual role that consists of pro-oxidant properties in the uremic condition and antioxidative properties under normal physiological conditions (Miyamoto et al. 2011). The increase in highly reactive radicals contributes to the oxidation of proteins and lipids. For example, the oxidation of LDL is known to occur in CKD patients (Ribeiro et al. 2012; Samouilidou et al. 2012). Furthermore, oxidative modifications of apoAI have been identified (Nicholls et al. 2005; Undurti et al. 2009; Zheng et al. 2004). ApoAI oxidation is dependent on the binding activity between apoAI and its receptors ABCA1 (Zheng et al. 2004) and SR-BI (Undurti et al. 2009). Therefore, ox-apoAI impairs HDL metabolism. In addition, an association between oxidative modifications of HDL and a higher risk for cardiovascular events in dialysis patients has been identified (Honda et al. 2012).

Another reactive compound that leads to protein modification is reactive cyanate, which induces the carbamylation of proteins. Cyanates emerge from the degradation of urea or via myeloperoxidase (MPO) at the sites of inflammation (Holzer et al. 2012; Sirpal 2009). CKD patients are prone to carbamylated proteins because urea levels are increased in the uremic condition, and these patients experience increased inflammation. MPO associates with HDL (Nicholls et al. 2005); thus, HDL proteins in addition to LDL proteins (Apostolov et al. 2005) become targets for carbamylation. Carbamylation impairs HDL function by decreasing the cholesterol efflux capacity of HDL from macrophages (Hadfield et al. 2013; Holzer et al. 2011b).

CKD patients are also prone to glycated protein modifications caused by insulin resistance, which is a condition that is frequently observed with reduced renal function (DeFronzo et al. 1981; Kobayashi et al. 2005). Insulin resistance appears 
to be associated with a high burden of oxidative stress. The reduction of oxidative stress by treatment with a superoxide dismutase/catalase mimetic reduces not only ROS production but also insulin resistance in a CKD mouse model (D'Apolito et al. 2010). The modified proteins are advanced glycated end products (AGEs), which are usually found at high levels in CKD patients. Glycated apoAI is likely an AGE (Lapolla et al. 2008). It has been speculated that these modified apoAIs have reduced RCT activity.

Additional proteins are also associated with HDL under physiological and pathophysiological conditions. Many proteins within HDL have been identified using a proteomic approach. Some proteins are increased, whereby other proteins are decreased in HD patients (Holzer et al. 2011a; Weichhart et al. 2012). However, an association between all of the proteins identified by proteome analysis and HDL functionality/dysfunctionality in the vessel wall could not be identified. Retinolbinding protein 4 (RBP4) was detected in the HDL from CKD patients, whereas it was not found within the HDL of healthy controls (Holzer et al. 2011a). Plasma levels of RBP4 were increased in dialysis patients (Frey et al. 2008), and the increase was dependent upon the CKD stage (Henze et al. 2010). Furthermore, surfactant protein B and $\alpha-1$-microglobulin/bikunin precursor proteins were significantly increased in ESRD patients (Weichhart et al. 2012). Transthyretin was not identified within the HDL from healthy controls, but was detectable in the HDL from dialysis patients (Holzer et al. 2011a). An overview of the identified proteins was recently presented (Holzer et al. 2011a; Weichhart et al. 2012).

\subsection{Loss of Protective Proteins or Lipids}

Oxidative stress participates in the pathogenesis and progression of CKD and was increased in CKD patients (Mimic-Oka et al. 1999; Puchades et al. 2013). This results from an imbalance of pro-oxidative and antioxidative signals that is favored by uremic toxins (Mimic-Oka et al. 1999). Navab et al. postulated that HDL itself can become pro-inflammatory (Navab et al. 2006). In this condition, serum lipoproteins are prone to oxidative modification. The enzymes linked to HDL that have an antioxidative capacity are thought to facilitate oxidative protection. A higher pro-inflammatory index of HDL in CKD patients resulted in a higher adjusted death hazard ratio (Kalantar-Zadeh et al. 2007). Furthermore, it was shown that the in vitro antioxidative function of HDL was impaired in CKD patients (Moradi et al. 2009). The primary antioxidative HDL-linked enzymes are PON and glutathione peroxidase, and of these two enzymes, PON is the most studied one. The PON family consists of three members: PON1, PON2, and PON3. In contrast to PON2, PON1 and PON3 are secreted in the blood and are associated within HDL (Macharia et al. 2012). PON1 remains the best-studied enzyme of this family in cardiovascular disease and kidney dysfunction. In CKD patients, proteomic analysis did not indicate a significant difference in PON1 compared with healthy individuals (Holzer et al. 2011a), whereas its enzyme activity was reduced in CKD patients (Dantoine et al. 1998; Kennedy et al. 2013; 
Moradi et al. 2009). The reduction negatively correlated with the CKD stage (Dantoine et al. 1998). For glutathione peroxidase, decreased concentration and activity were identified in dialysis patients (Moradi et al. 2009).

The loss of this antioxidative capacity combined with an increased level of pro-oxidative molecules (see below) may, at least in part, account for the increased oxidative stress in CKD patients.

A component that contributes to several of the protective functions of HDL is sphingosine-1-phosphate (S1P) (Nofer et al. 2004, 2007; Schuchardt et al. 2011; Theilmeier et al. 2006). HDL-associated apoM binds S1P (Christoffersen et al. 2011). In CKD patients, apoM levels are decreased (Holzer et al. 2011a), which may lead to higher levels of S1P free from HDL. There are several indications that non-HDL-bound S1P signaling differs compared with HDL-bound S1P (Schuchardt et al. 2011).

\subsection{Increase of Molecules within HDL with a Fatal Function in the Vascular Wall}

In vitro and in vivo studies and/or clinical trials have identified proteins that accumulate within HDL. Interestingly, the albumin content in HDL from uremic patients was elevated, and apolipoprotein displacement may occur (Holzer et al. 2011a).

The acute phase protein serum amyloid A (SAA), which is secreted by the liver during inflammation, is primarily transported by HDL within the blood (Uhlar and Whitehead 1999). In uremic patients, elevated SAA (Holzer et al. 2011a; Tolle et al. 2012; Weichhart et al. 2012; Zimmermann et al. 1999) is a sign of a chronic inflammatory status. This is closely related to an increased cardiovascular risk in humans (Zimmermann et al. 1999). In vitro studies support these findings, as the accumulation of SAA in HDL was correlated with a reduced anti-inflammatory capacity of HDL and a pro-inflammatory potential (Tolle et al. 2012; Weichhart et al. 2012). Furthermore, the cholesterol efflux capacity was decreased when the SAA level dramatically increased during acute sepsis (Annema et al. 2010). In addition, SAA accumulation results in the replacement of apoAI and influences HDL remodeling and metabolism. Nonetheless, the replacement was not identified in all patient cohorts (Tolle et al. 2012), which may be because of the different experimental settings. A displacement of other protective proteins during the acute phase response by SAA was also observed for PON1 and PAF-AH (Van Lenten et al. 1995). Thus, SAA enrichment within HDL affects the anti-inflammatory response. Recently, a pro-inflammatory response of SAA-rich HDL in CKD patients was observed (Tolle et al. 2012; Weichhart et al. 2012). The effects of SAA accumulation on the cholesterol efflux function of HDL remain controversial. In some experiments, a reduction of the cholesterol efflux capacity of HDL was observed if it was enriched with SAA (Artl et al. 2000; Marsche et al. 2007), whereas other studies found normal efflux capacity even with SAA-rich HDL (Banka et al. 1995; van der Westhuyzen et al. 2005). 
Furthermore, phospholipases (PLA) associated with cardiovascular mortality are elevated in uremic patients. For example, lipoprotein-associated PLA (Lp-PLA) 2 was increased in uremic patients (Holzer et al. 2011a). The secreted PLA 2 (sPLA2) concentration and activity were also higher in ESRD patients. This elevation contributes to excessive oxidative stress in these patients (van der Giet et al. 2010a).

Dimethylarginines (DMAs), such as asymmetric dimethylarginine (ADMA) and its structural isomer symmetric DMA (SDMA), have been correlated with cardiovascular risk factors. As uremic toxins, they have been associated with cardiovascular outcomes and renal dysfunction (Duranton et al. 2012; Kielstein et al. 2006). DMAs originate from protein proteolysis and are mainly excreted in the urine. DMAs influence nitric oxide (NO) synthesis and negatively influence its vascular protective effects (Bode-Boger et al. 2006). The accumulation of SDMA in HDL from CKD patients and its association with decreased NO have recently been demonstrated (Speer et al. 2013).

MPO is another protein associated with the pathogenesis of cardiovascular disease because of its pro-oxidative and carbamylating potential (Nicholls et al. 2005; Undurti et al. 2009; Zheng et al. 2004). As discussed earlier, MPO associates with HDL (Nicholls et al. 2005) and contributes to reduced RCT in inflammatory diseases (Annema et al. 2010; Zheng et al. 2004). Furthermore, MPO-derived oxidative products modify apoAI (Hadfield et al. 2013). The modifications induced by MPO result in a pro-inflammatory HDL particle (Undurti et al. 2009). In patients with diabetes mellitus type 2, MPO activity was increased in HDL (Sorrentino et al. 2010). Interestingly, in a CKD cohort, the MPO plasma level decreased with advancing renal failure (Madhusudhana Rao et al. 2011). Further studies are necessary to determine the role of MPO in HDL dysfunction in a CKD cohort.

The HDL from ESRD patients on HD was less effective at accepting cholesterol from macrophages compared with the HDL from healthy subjects (Holzer et al. 2011a; Yamamoto et al. 2012). The reverse cholesterol transport may be affected in uremic patients.

\section{Possibility of Functional Restoration of HDL}

HDL function has been a recent focus of experimental research. With respect to weak effects on cardiovascular outcome after an increase of HDL quantity in CKD patients, HDL function capacity appears important for the design of new therapeutic approaches. Therefore, the question arose whether structural modifications and associated dysfunctions under uremic conditions are reversible. The best approach to test this hypothesis in the case of renal function is to study patients after successful renal transplantation. A limitation of this model is that these patients often require immunosuppressive drugs, which may affect lipid metabolism and function (Badiou et al. 2009). Some investigations have attempted to observe changes in HDL function after renal transplantation. Dantoine and coworkers 
reported that the PON enzyme activity in patients after kidney transplantation was comparable to that in control subjects, whereas in dialysis patients, it was decreased (Dantoine et al. 1998). Furthermore, the anti-inflammatory capacity of HDL from ESRD patients compared with healthy controls increased after successful renal transplantation (van der Giet et al. 2010b). The observed effect appears to be related to a decreased SAA level in transplant recipients. Other indicators of the reversibility of HDL dysfunction are based on studies with chronic heart failure patients. In this cohort, exercise training, which is an accepted intervention strategy to decrease cardiovascular risk in heart failure patients, resulted in increased HDL. The authors demonstrated that changes in HDL function induced by exercise training correlated with improved endothelial function (Adams et al. 2013).

According to these data it has been suggested that a restoration of HDL is possible. The lipid metabolism and the composition of different lipoprotein particles are primarily influenced by the metabolic condition. To date, little information is available regarding whether the CKD stage before transplantation is dependent on the HDL functionality after kidney transplantation or whether a point-of-no-return exists for functional restoration, vessel damage, and cardiovascular risk.

\section{Laboratory Tests to Measure HDL Function}

According to previous clinical and experimental trials, it has become clear that HDL particle modifications in disease conditions are associated with reduced HDL function; specific factors that determine HDL functionality remain unclear. It is known that various structural features are associated with HDL function, which can be measured by in vitro studies. A limitation arises in the difficulty of comparing experimental results. The standardization of the experimental design for HDL isolation, separation of proteins/lipids, sample preparation for proteomic approaches, and detection methods for components within HDL would help to overcome certain limitations that may result in discrepancies between findings. In addition, in vitro functionality assays are very complex and further hamper comparability. The complexity and cost preclude these tests from routine clinical laboratory analyses, thus limiting the validation of experimental findings of functionality in large clinical trials. Standardization, validation, and optimization for high throughput must first be established.

Recently, an overview of the laboratory tests that measure HDL subclasses (shape, density) and several HDL functions was described (Eren et al. 2012). There is a growing need to identify an optimal biomarker that describes HDL functionality. The development of reproducible, standardized, and validated methods to assess HDL function for routine use is of substantial interest. The knowledge regarding individual HDL function can help identify patients who may benefit from HDL-C increasing therapy or patients with a normal HDL-C level but at particularly high risk for cardiovascular events. 


\section{Conclusion and Perspective}

HDL is a plasma lipoprotein with many pleiotropic protective functions in the vascular wall, including anti-atherosclerotic properties. Emerging evidence from clinical and laboratory studies indicates that HDL-C plasma levels in humans do not adequately represent HDL function. The pleiotropic protective effects of HDL depend on its composition, which is influenced by pathophysiological conditions. With the decline of renal function, HDL modifications occur. Evidence suggests that HDL composition, rather than plasma level, may be an important determinant for its pleiotropic protective function in the vascular wall. The goal is to identify robust biomarkers that describe HDL functionality and are measurable in validated, standardized assays that can be used routinely. Improvement of HDL functionality may serve as an interesting therapeutic target in the future for populations beyond CKD patients.

Acknowledgements The authors thank Jaqueline Herrmann for proofreading the manuscript.

The research projects of the authors are supported by the EFSD/Boehringer Ingelheim award (M.vdG), the Hans und Gertie Fischer-Stiftung (M.T), and the Peter und Traudl Engelhorn Stiftung scholarship (M.S). M.vdG is a member of the European Cooperation in Science and Technology (COST) Action "HDLnet" (BM904).

Conflict of Interest Statement None declared.

Open Access This chapter is distributed under the terms of the Creative Commons Attribution Noncommercial License, which permits any noncommercial use, distribution, and reproduction in any medium, provided the original author(s) and source are credited.

\section{References}

Adams V, Besler C, Fischer T, Riwanto M, Noack F, Hollriegel R, Oberbach A, Jehmlich N, Volker U, Winzer EB, Lenk K, Hambrecht R, Schuler G, Linke A, Landmesser U, Erbs S (2013) Exercise training in patients with chronic heart failure promotes restoration of highdensity lipoprotein functional properties. Circ Res 113(12):1345-1355

AIM-HIGH Investigators (2011) The role of niacin in raising high-density lipoprotein cholesterol to reduce cardiovascular events in patients with atherosclerotic cardiovascular disease and optimally treated low-density lipoprotein cholesterol: baseline characteristics of study participants. The atherothrombosis intervention in metabolic syndrome with low HDL/high triglycerides: impact on global health outcomes (AIM-HIGH) trial. Am Heart J 161 (3):538-543

Annema W, von Eckardstein A (2013) High-density lipoproteins. Multifunctional but vulnerable protections from atherosclerosis. Circ J 77(10):2432-2448

Annema W, Nijstad N, Tolle M, de Boer JF, Buijs RV, Heeringa P, van der Giet M, Tietge UJ (2010) Myeloperoxidase and serum amyloid A contribute to impaired in vivo reverse cholesterol transport during the acute phase response but not group IIA secretory phospholipase $\mathrm{A}(2)$. J Lipid Res 51(4):743-754

Apostolov EO, Shah SV, Ok E, Basnakian AG (2005) Quantification of carbamylated LDL in human sera by a new sandwich ELISA. Clin Chem 51(4):719-728 
Apostolov EO, Ray D, Savenka AV, Shah SV, Basnakian AG (2010) Chronic uremia stimulates LDL carbamylation and atherosclerosis. J Am Soc Nephrol 21(11):1852-1857

Appel LJ (2004) Beyond (or back to) traditional risk factors: preventing cardiovascular disease in patients with chronic kidney disease. Ann Intern Med 140(1):60-61

Arsenault BJ, Lemieux I, Despres JP, Gagnon P, Wareham NJ, Stroes ES, Kastelein JJ, Khaw KT, Boekholdt SM (2009) HDL particle size and the risk of coronary heart disease in apparently healthy men and women: the EPIC-Norfolk prospective population study. Atherosclerosis 206 (1):276-281

Artl A, Marsche G, Lestavel S, Sattler W, Malle E (2000) Role of serum amyloid A during metabolism of acute-phase HDL by macrophages. Arterioscler Thromb Vasc Biol 20 (3):763-772

Asselbergs FW, Diercks GF, Hillege HL, van Boven AJ, Janssen WM, Voors AA, de Zeeuw D, de Jong PE, van Veldhuisen DJ, van Gilst WH (2004) Effects of fosinopril and pravastatin on cardiovascular events in subjects with microalbuminuria. Circulation 110(18):2809-2816

Atthobari J, Brantsma AH, Gansevoort RT, Visser ST, Asselbergs FW, van Gilst WH, de Jong PE, de Jong-van den Berg LT (2006) The effect of statins on urinary albumin excretion and glomerular filtration rate: results from both a randomized clinical trial and an observational cohort study. Nephrol Dial Transplant 21(11):3106-3114

Badiou S, Cristol JP, Mourad G (2009) Dyslipidemia following kidney transplantation: diagnosis and treatment. Curr Diab Rep 9(4):305-311

Baigent C, Keech A, Kearney PM, Blackwell L, Buck G, Pollicino C, Kirby A, Sourjina T, Peto R, Collins R, Simes R (2005) Efficacy and safety of cholesterol-lowering treatment: prospective meta-analysis of data from 90,056 participants in 14 randomised trials of statins. Lancet 366 (9493):1267-1278

Baigent C, Landray MJ, Reith C, Emberson J, Wheeler DC, Tomson C, Wanner C, Krane V, Cass A, Craig J, Neal B, Jiang L, Hooi LS, Levin A, Agodoa L, Gaziano M, Kasiske B, Walker R, Massy ZA, Feldt-Rasmussen B, Krairittichai U, Ophascharoensuk V, Fellstrom B, Holdaas H, Tesar V, Wiecek A, Grobbee D, de Zeeuw D, Gronhagen-Riska C, Dasgupta T, Lewis D, Herrington W, Mafham M, Majoni W, Wallendszus K, Grimm R, Pedersen T, Tobert J, Armitage J, Baxter A, Bray C, Chen Y, Chen Z, Hill M, Knott C, Parish S, Simpson D, Sleight P, Young A, Collins R (2011) The effects of lowering LDL cholesterol with simvastatin plus ezetimibe in patients with chronic kidney disease (Study of Heart and Renal Protection): a randomised placebo-controlled trial. Lancet 377(9784):2181-2192

Banka CL, Yuan T, de Beer MC, Kindy M, Curtiss LK, de Beer FC (1995) Serum amyloid A (SAA): influence on HDL-mediated cellular cholesterol efflux. J Lipid Res 36(5):1058-1065

Baragetti A, Norata GD, Sarcina C, Rastelli F, Grigore L, Garlaschelli K, Uboldi P, Baragetti I, Pozzi C, Catapano AL (2013) High density lipoprotein cholesterol levels are an independent predictor of the progression of chronic kidney disease. J Intern Med 274(3):252-262

Barter PJ, Caulfield M, Eriksson M, Grundy SM, Kastelein JJ, Komajda M, Lopez-Sendon J, Mosca L, Tardif JC, Waters DD, Shear CL, Revkin JH, Buhr KA, Fisher MR, Tall AR, Brewer B (2007) Effects of torcetrapib in patients at high risk for coronary events. N Engl J Med 357 (21):2109-2122

Bode-Boger SM, Scalera F, Kielstein JT, Martens-Lobenhoffer J, Breithardt G, Fobker M, Reinecke H (2006) Symmetrical dimethylarginine: a new combined parameter for renal function and extent of coronary artery disease. J Am Soc Nephrol 17(4):1128-1134

Boden WE, Probstfield JL, Anderson T, Chaitman BR, Desvignes-Nickens P, Koprowicz K, McBride R, Teo K, Weintraub W (2011) Niacin in patients with low HDL cholesterol levels receiving intensive statin therapy. N Engl J Med 365(24):2255-2267

Brouwers FP, Asselbergs FW, Hillege HL, de Boer RA, Gansevoort RT, van Veldhuisen DJ, van Gilst WH (2011) Long-term effects of fosinopril and pravastatin on cardiovascular events in subjects with microalbuminuria: ten years of follow-up of Prevention of Renal and Vascular End-stage Disease Intervention Trial (PREVEND IT). Am Heart J 161(6):1171-1178 
Calabresi L, Gomaraschi M, Franceschini G (2003) Endothelial protection by high-density lipoproteins: from bench to bedside. Arterioscler Thromb Vasc Biol 23(10):1724-1731

Camont L, Chapman MJ, Kontush A (2011) Biological activities of HDL subpopulations and their relevance to cardiovascular disease. Trends Mol Med 17(10):594-603

Cannon CP, Shah S, Dansky HM, Davidson M, Brinton EA, Gotto AM, Stepanavage M, Liu SX, Gibbons P, Ashraf TB, Zafarino J, Mitchel Y, Barter P (2010) Safety of anacetrapib in patients with or at high risk for coronary heart disease. N Engl J Med 363(25):2406-2415

Chen SC, Hung CC, Kuo MC, Lee JJ, Chiu YW, Chang JM, Hwang SJ, Chen HC (2013) Association of dyslipidemia with renal outcomes in chronic kidney disease. PLoS ONE 8(2): e55643

Christoffersen C, Obinata H, Kumaraswamy SB, Galvani S, Ahnstrom J, Sevvana M, EgererSieber C, Muller YA, Hla T, Nielsen LB, Dahlback B (2011) Endothelium-protective sphingosine-1-phosphate provided by HDL-associated apolipoprotein M. Proc Natl Acad Sci USA 108(23):9613-9618

Collins R, Armitage J, Parish S, Sleigh P, Peto R (2003) MRC/BHF Heart Protection Study of cholesterol-lowering with simvastatin in 5963 people with diabetes: a randomised placebocontrolled trial. Lancet 361(9374):2005-2016

Collins AJ, Foley RN, Herzog C, Chavers B, Gilbertson D, Ishani A, Johansen K, Kasiske B, Kutner N, Liu J, St Peter W, Ding S, Guo H, Kats A, Lamb K, Li S, Roberts T, Skeans M, Snyder J, Solid C, Thompson B, Weinhandl E, Xiong H, Yusuf A, Zaun D, Arko C, Chen SC, Daniels F, Ebben J, Frazier E, Hanzlik C, Johnson R, Sheets D, Wang X, Forrest B, Constantini E, Everson S, Eggers P, Agodoa L (2013) US renal data system 2012 annual data report. Am J Kidney Dis 61(1 Suppl 1):A7, e1-e476

Coresh J, Longenecker JC, Miller ER 3rd, Young HJ, Klag MJ (1998) Epidemiology of cardiovascular risk factors in chronic renal disease. J Am Soc Nephrol 9(12 Suppl):S24-S30

Dantoine TF, Debord J, Charmes JP, Merle L, Marquet P, Lachatre G, Leroux-Robert C (1998) Decrease of serum paraoxonase activity in chronic renal failure. J Am Soc Nephrol 9 (11):2082-2088

D'Apolito M, Du X, Zong H, Catucci A, Maiuri L, Trivisano T, Pettoello-Mantovani M, Campanozzi A, Raia V, Pessin JE, Brownlee M, Giardino I (2010) Urea-induced ROS generation causes insulin resistance in mice with chronic renal failure. J Clin Invest 120 (1):203-213

DeFronzo RA, Alvestrand A, Smith D, Hendler R, Hendler E, Wahren J (1981) Insulin resistance in uremia. J Clin Investig 67(2):563-568

Di Angelantonio E, Sarwar N, Perry P, Kaptoge S, Ray KK, Thompson A, Wood AM, Lewington S, Sattar N, Packard CJ, Collins R, Thompson SG, Danesh J (2009) Major lipids, apolipoproteins, and risk of vascular disease. JAMA 302(18):1993-2000

Dullaart RP, Gansevoort RT, Dikkeschei BD, de Zeeuw D, de Jong PE, Van Tol A (1993) Role of elevated lecithin: cholesterol acyltransferase and cholesteryl ester transfer protein activities in abnormal lipoproteins from proteinuric patients. Kidney Int 44(1):91-97

Duranton F, Cohen G, De Smet R, Rodriguez M, Jankowski J, Vanholder R, Argiles A (2012) Normal and pathologic concentrations of uremic toxins. J Am Soc Nephrol 23(7):1258-1270

El Harchaoui K, Arsenault BJ, Franssen R, Despres JP, Hovingh GK, Stroes ES, Otvos JD, Wareham NJ, Kastelein JJ, Khaw KT, Boekholdt SM (2009) High-density lipoprotein particle size and concentration and coronary risk. Ann Intern Med 150(2):84-93

Eren E, Yilmaz N, Aydin O (2012) High density lipoprotein and it's dysfunction. Open Biochem J 6:78-93

Fellstrom B, Holdaas H, Jardine AG, Svensson MK, Gottlow M, Schmieder RE, Zannad F (2009a) Cardiovascular disease in patients with renal disease: the role of statins. Curr Med Res Opin 25 (1):271-285

Fellstrom BC, Jardine AG, Schmieder RE, Holdaas H, Bannister K, Beutler J, Chae DW, Chevaile A, Cobbe SM, Gronhagen-Riska C, De Lima JJ, Lins R, Mayer G, McMahon AW, Parving HH, Remuzzi G, Samuelsson O, Sonkodi S, Sci D, Suleymanlar G, Tsakiris D, 
Tesar V, Todorov V, Wiecek A, Wuthrich RP, Gottlow M, Johnsson E, Zannad F (2009b) Rosuvastatin and cardiovascular events in patients undergoing hemodialysis. N Engl J Med 360(14):1395-1407

Foley RN, Parfrey PS, Sarnak MJ (1998) Epidemiology of cardiovascular disease in chronic renal disease. J Am Soc Nephrol 9(12 Suppl):S16-S23

Frey SK, Nagl B, Henze A, Raila J, Schlosser B, Berg T, Tepel M, Zidek W, Weickert MO, Pfeiffer AF, Schweigert FJ (2008) Isoforms of retinol binding protein 4 (RBP4) are increased in chronic diseases of the kidney but not of the liver. Lipids Health Dis 7:29

Fried LF, Orchard TJ, Kasiske BL (2001) Effect of lipid reduction on the progression of renal disease: a meta-analysis. Kidney Int 59(1):260-269

Gordon T, Castelli WP, Hjortland MC, Kannel WB, Dawber TR (1977) High density lipoprotein as a protective factor against coronary heart disease. The Framingham study. Am J Med 62 (5):707-714

Gutstein DE, Krishna R, Johns D, Surks HK, Dansky HM, Shah S, Mitchel YB, Arena J, Wagner JA (2012) Anacetrapib, a novel CETP inhibitor: pursuing a new approach to cardiovascular risk reduction. Clin Pharmacol Ther 91(1):109-122

Hadfield KA, Pattison DI, Brown BE, Hou L, Rye KA, Davies MJ, Hawkins CL (2013) Myeloperoxidase-derived oxidants modify apolipoprotein A-I and generate dysfunctional high-density lipoproteins: comparison of hypothiocyanous acid (HOSCN) with hypochlorous acid (HOCl). Biochem J 449(2):531-542

Henze A, Frey SK, Raila J, Scholze A, Spranger J, Weickert MO, Tepel M, Zidek W, Schweigert FJ (2010) Alterations of retinol-binding protein 4 species in patients with different stages of chronic kidney disease and their relation to lipid parameters. Biochem Biophys Res Commun 393(1):79-83

Hirano T (2013) Abnormal lipoprotein metabolism in diabetic nephropathy. Clin Exp Nephrol 1-4

Holdaas H, Fellstrom B, Jardine AG, Holme I, Nyberg G, Fauchald P, Gronhagen-Riska C, Madsen S, Neumayer HH, Cole E, Maes B, Ambuhl P, Olsson AG, Hartmann A, Solbu DO, Pedersen TR (2003) Effect of fluvastatin on cardiac outcomes in renal transplant recipients: a multicentre, randomised, placebo-controlled trial. Lancet 361(9374):2024-2031

Holdaas H, Holme I, Schmieder RE, Jardine AG, Zannad F, Norby GE, Fellstrom BC (2011) Rosuvastatin in diabetic hemodialysis patients. J Am Soc Nephrol 22(7):1335-1341

Holzer M, Birner-Gruenberger R, Stojakovic T, El-Gamal D, Binder V, Wadsack C, Heinemann A, Marsche G (2011a) Uremia alters HDL composition and function. J Am Soc Nephrol 22(9):1631-1641

Holzer M, Gauster M, Pfeifer T, Wadsack C, Fauler G, Stiegler P, Koefeler H, Beubler E, Schuligoi R, Heinemann A, Marsche G (2011b) Protein carbamylation renders high-density lipoprotein dysfunctional. Antioxid Redox Signal 14(12):2337-2346

Holzer M, Zangger K, El-Gamal D, Binder V, Curcic S, Konya V, Schuligoi R, Heinemann A, Marsche G (2012) Myeloperoxidase-derived chlorinating species induce protein carbamylation through decomposition of thiocyanate and urea: novel pathways generating dysfunctional high-density lipoprotein. Antioxid Redox Signal 17(8):1043-1052

Home PD, Pocock SJ, Beck-Nielsen H, Curtis PS, Gomis R, Hanefeld M, Jones NP, Komajda M, McMurray JJ (2009) Rosiglitazone evaluated for cardiovascular outcomes in oral agent combination therapy for type 2 diabetes (RECORD): a multicentre, randomised, open-label trial. Lancet 373(9681):2125-2135

Honda H, Ueda M, Kojima S, Mashiba S, Michihata T, Takahashi K, Shishido K, Akizawa T (2012) Oxidized high-density lipoprotein as a risk factor for cardiovascular events in prevalent hemodialysis patients. Atherosclerosis 220(2):493-501

HPS2-THRIVE Collaborative Group (2013) HPS2-THRIVE randomized placebo-controlled trial in 25673 high-risk patients of ER niacin/laropiprant: trial design, pre-specified muscle and liver outcomes, and reasons for stopping study treatment. Eur Heart J 34(17):1279-1291

Ikewaki K (2013) In vivo kinetic studies to further understand pathogenesis of abnormal lipoprotein metabolism in chronic kidney disease. Clin Exp Nephrol 1-4 
Jacobson TA (2013) Lipoprotein(a), cardiovascular disease, and contemporary management. Mayo Clin Proc 88(11):1294-1311

Kalantar-Zadeh K, Kopple JD, Kamranpour N, Fogelman AM, Navab M (2007) HDL-inflammatory index correlates with poor outcome in hemodialysis patients. Kidney Int 72(9):1149-1156

Kaysen GA (2009) Biochemistry and biomarkers of inflamed patients: why look, what to assess. Clin J Am Soc Nephrol 4(Suppl 1):S56-S63

Keane WF, Tomassini JE, Neff DR (2013) Lipid abnormalities in patients with chronic kidney disease: implications for the pathophysiology of atherosclerosis. J Atheroscler Thromb 20 (2):123-133

Kennedy DJ, Wilson Tang WH, Fan Y, Wu Y, Mann S, Pepoy M, Hazen SL (2013) Diminished antioxidant activity of high-density lipoprotein-associated proteins in chronic kidney disease. $\mathrm{J}$ Am Heart Assoc 2(2):e000104

Khovidhunkit W, Kim MS, Memon RA, Shigenaga JK, Moser AH, Feingold KR, Grunfeld C (2004) Effects of infection and inflammation on lipid and lipoprotein metabolism: mechanisms and consequences to the host. J Lipid Res 45(7):1169-1196

Kielstein JT, Salpeter SR, Bode-Boeger SM, Cooke JP, Fliser D (2006) Symmetric dimethylarginine (SDMA) as endogenous marker of renal function-a meta-analysis. Nephrol Dial Transplant 21(9):2446-2451

Kilpatrick RD, McAllister CJ, Kovesdy CP, Derose SF, Kopple JD, Kalantar-Zadeh K (2007) Association between serum lipids and survival in hemodialysis patients and impact of race. $\mathrm{J}$ Am Soc Nephrol 18(1):293-303

Klin M, Smogorzewski M, Ni Z, Zhang G, Massry SG (1996) Abnormalities in hepatic lipase in chronic renal failure: role of excess parathyroid hormone. J Clin Invest 97(10):2167-2173

Kobayashi S, Maesato K, Moriya H, Ohtake T, Ikeda T (2005) Insulin resistance in patients with chronic kidney disease. Am J Kidney Dis 45(2):275-280

Kovesdy CP, Anderson JE, Kalantar-Zadeh K (2007) Inverse association between lipid levels and mortality in men with chronic kidney disease who are not yet on dialysis: effects of case mix and the malnutrition-inflammation-cachexia syndrome. J Am Soc Nephrol 18(1):304-311

Lamprea-Montealegre JA, McClelland RL, Astor BC, Matsushita K, Shlipak M, de Boer IH, Szklo M (2013) Chronic kidney disease, plasma lipoproteins, and coronary artery calcium incidence: the Multi-Ethnic Study of Atherosclerosis. Arterioscler Thromb Vasc Biol 33(3):652-658

Lapolla A, Brioschi M, Banfi C, Tremoli E, Cosma C, Bonfante L, Cristoni S, Seraglia R, Traldi P (2008) Nonenzymatically glycated lipoprotein ApoA-I in plasma of diabetic and nephropathic patients. Ann N Y Acad Sci 1126:295-299

LaRosa JC, Grundy SM, Waters DD, Shear C, Barter P, Fruchart JC, Gotto AM, Greten H, Kastelein JJ, Shepherd J, Wenger NK (2005) Intensive lipid lowering with atorvastatin in patients with stable coronary disease. N Engl J Med 352(14):1425-1435

Levey AS, Eckardt KU, Tsukamoto Y, Levin A, Coresh J, Rossert J, De Zeeuw D, Hostetter TH, Lameire N, Eknoyan G (2005) Definition and classification of chronic kidney disease: a position statement from Kidney Disease: Improving Global Outcomes (KDIGO). Kidney Int 67(6):2089-2100

Liang K, Vaziri ND (1999) Down-regulation of hepatic high-density lipoprotein receptor, SR-B1, in nephrotic syndrome. Kidney Int 56(2):621-626

Liang K, Oveisi F, Vaziri ND (1998) Role of secondary hyperparathyroidism in the genesis of hypertriglyceridemia and VLDL receptor deficiency in chronic renal failure. Kidney Int 53 (3):626-630

Linsel-Nitschke P, Tall AR (2005) HDL as a target in the treatment of atherosclerotic cardiovascular disease. Nat Rev Drug Discov 4(3):193-205

Longenecker JC, Klag MJ, Marcovina SM, Liu YM, Jaar BG, Powe NR, Fink NE, Levey AS, Coresh J (2005) High lipoprotein(a) levels and small apolipoprotein(a) size prospectively predict cardiovascular events in dialysis patients. J Am Soc Nephrol 16(6):1794-1802 
Macharia M, Hassan MS, Blackhurst D, Erasmus RT, Matsha TE (2012) The growing importance of PON1 in cardiovascular health: a review. J Cardiovasc Med 13(7):443-453

Mackey RH, Greenland P, Goff DC Jr, Lloyd-Jones D, Sibley CT, Mora S (2012) High-density lipoprotein cholesterol and particle concentrations, carotid atherosclerosis, and coronary events: MESA (multi-ethnic study of atherosclerosis). J Am Coll Cardiol 60(6):508-516

Madhusudhana Rao A, Anand U, Anand CV (2011) Myeloperoxidase in chronic kidney disease. Indian J Clin Biochem 26(1):28-31

Marsche G, Frank S, Raynes JG, Kozarsky KF, Sattler W, Malle E (2007) The lipidation status of acute-phase protein serum amyloid A determines cholesterol mobilization via scavenger receptor class B, type I. Biochem J 402(1):117-124

Marz W, Genser B, Drechsler C, Krane V, Grammer TB, Ritz E, Stojakovic T, Scharnagl H, Winkler K, Holme I, Holdaas H, Wanner C (2011) Atorvastatin and low-density lipoprotein cholesterol in type 2 diabetes mellitus patients on hemodialysis. Clin J Am Soc Nephrol 6 (6): $1316-1325$

Miida T, Miyazaki O, Hanyu O, Nakamura Y, Hirayama S, Narita I, Gejyo F, Ei I, Tasaki K, Kohda Y, Ohta T, Yata S, Fukamachi I, Okada M (2003) LCAT-dependent conversion of prebeta1-HDL into alpha-migrating HDL is severely delayed in hemodialysis patients. J Am Soc Nephrol 14(3):732-738

Mimic-Oka J, Simic T, Djukanovic L, Reljic Z, Davicevic Z (1999) Alteration in plasma antioxidant capacity in various degrees of chronic renal failure. Clin Nephrol 51(4):233-241

Miyamoto Y, Watanabe H, Otagiri M, Maruyama T (2011) New insight into the redox properties of uremic solute indoxyl sulfate as a pro- and anti-oxidant. Ther Apher Dial 15(2):129-131

Mizobuchi M, Towler D, Slatopolsky E (2009) Vascular calcification: the killer of patients with chronic kidney disease. J Am Soc Nephrol 20(7):1453-1464

Moe SM, Sprague SM (2012) Chronic kidney disease-mineral bone disorder. In: Taal MW (ed) Brenner and Rector's the kidney, 9th edn. Elsevier, Philadelphia, pp 2021-2058

Moradi H, Pahl MV, Elahimehr R, Vaziri ND (2009) Impaired antioxidant activity of high-density lipoprotein in chronic kidney disease. Transl Res 153(2):77-85

Moradi H, Sica DA, Kalantar-Zadeh K (2013) Cardiovascular burden associated with uremic toxins in patients with chronic kidney disease. Am J Nephrol 38(2):136-148

Mori K, Shioi A, Jono S, Nishizawa Y, Morii H (1999) Dexamethasone enhances In vitro vascular calcification by promoting osteoblastic differentiation of vascular smooth muscle cells. Arterioscler Thromb Vasc Biol 19(9):2112-2118

Muntner P, Hamm LL, Kusek JW, Chen J, Whelton PK, He J (2004) The prevalence of nontraditional risk factors for coronary heart disease in patients with chronic kidney disease. Ann Intern Med 140(1):9-17

National Kidney Foundation (2003) I. Introduction. Am J Kidney Dis 41:S11-S21

Navab M, Imes SS, Hama SY, Hough GP, Ross LA, Bork RW, Valente AJ, Berliner JA, Drinkwater DC, Laks H et al (1991) Monocyte transmigration induced by modification of low density lipoprotein in cocultures of human aortic wall cells is due to induction of monocyte chemotactic protein 1 synthesis and is abolished by high density lipoprotein. J Clin Invest 88 (6):2039-2046

Navab M, Anantharamaiah GM, Reddy ST, Van Lenten BJ, Ansell BJ, Fogelman AM (2006) Mechanisms of disease: proatherogenic HDL-an evolving field. Nat Clin Pract Endocrinol Metab 2(9):504-511

Navab M, Reddy ST, Van Lenten BJ, Fogelman AM (2011) HDL and cardiovascular disease: atherogenic and atheroprotective mechanisms. Nat Rev Cardiol 8(4):222-232

Nicholls SJ, Zheng L, Hazen SL (2005) Formation of dysfunctional high-density lipoprotein by myeloperoxidase. Trends Cardiovasc Med 15(6):212-219

Nofer JR, van der Giet M, Tolle M, Wolinska I, von Wnuck LK, Baba HA, Tietge UJ, Godecke A, Ishii I, Kleuser B, Schafers M, Fobker M, Zidek W, Assmann G, Chun J, Levkau B (2004) HDL induces NO-dependent vasorelaxation via the lysophospholipid receptor S1P3. J Clin Invest 113(4):569-581 
Nofer JR, Bot M, Brodde M, Taylor PJ, Salm P, Brinkmann V, van Berkel T, Assmann G, Biessen EA (2007) FTY720, a synthetic sphingosine 1 phosphate analogue, inhibits development of atherosclerosis in low-density lipoprotein receptor-deficient mice. Circulation 115(4):501-508

Odden MC, Tager IB, Gansevoort RT, Bakker SJ, Fried LF, Newman AB, Katz R, Satterfield S, Harris TB, Sarnak MJ, Siscovick D, Shlipak MG (2013) Hypertension and low HDL cholesterol were associated with reduced kidney function across the age spectrum: a collaborative study. Ann Epidemiol 23(3):106-111

Pahl MV, Ni Z, Sepassi L, Moradi H, Vaziri ND (2009) Plasma phospholipid transfer protein, cholesteryl ester transfer protein and lecithin:cholesterol acyltransferase in end-stage renal disease (ESRD). Nephrol Dial Transplant 24(8):2541-2546

Peev V, Nayer A, Contreras G (2014) Dyslipidemia, malnutrition, inflammation, cardiovascular disease and mortality in chronic kidney disease. Curr Opin Lipidol 25(1):54-60

Puchades MJ, Saez G, Munoz MC, Gonzalez M, Torregrosa I, Juan I, Miguel A (2013) Study of oxidative stress in patients with advanced renal disease and undergoing either hemodialysis or peritoneal dialysis. Clin Nephrol 80(3):177-186

Rahman M, Baimbridge C, Davis BR, Barzilay J, Basile JN, Henriquez MA, Huml A, Kopyt N, Louis GT, Pressel SL, Rosendorff C, Sastrasinh S, Stanford C (2008) Progression of kidney disease in moderately hypercholesterolemic, hypertensive patients randomized to pravastatin versus usual care: a report from the antihypertensive and lipid-lowering treatment to prevent heart attack trial (ALLHAT). Am J Kidney Dis 52(3):412-424

Ribeiro S, Faria Mdo S, Silva G, Nascimento H, Rocha-Pereira P, Miranda V, Vieira E, Santos R, Mendonca D, Quintanilha A, Costa E, Belo L, Santos-Silva A (2012) Oxidized low-density lipoprotein and lipoprotein(a) levels in chronic kidney disease patients under hemodialysis: influence of adiponectin and of a polymorphism in the apolipoprotein(a) gene. Hemodial Int 16 (4):481-490

Rubins HB, Robins SJ, Iwane MK, Boden WE, Elam MB, Fye CL, Gordon DJ, Schaefer EJ, Schectman G, Wittes JT (1993) Rationale and design of the Department of Veterans Affairs High-Density Lipoprotein Cholesterol Intervention Trial (HIT) for secondary prevention of coronary artery disease in men with low high-density lipoprotein cholesterol and desirable low-density lipoprotein cholesterol. Am J Cardiol 71(1):45-52

Sahebkar A, Chew GT, Watts GF (2014) New peroxisome proliferator-activated receptor agonists: potential treatments for atherogenic dyslipidemia and non-alcoholic fatty liver disease. Expert Opin Pharmacother 15(4):493-503

Saland JM, Ginsberg HN (2007) Lipoprotein metabolism in chronic renal insufficiency. Pediatr Nephrol 22(8):1095-1112

Samouilidou EC, Karpouza AP, Kostopoulos V, Bakirtzi T, Pantelias K, Petras D, TzanatouExarchou H, Grapsa EJ (2012) Lipid abnormalities and oxidized LDL in chronic kidney disease patients on hemodialysis and peritoneal dialysis. Ren Fail 34(2):160-164

Sandhu S, Wiebe N, Fried LF, Tonelli M (2006) Statins for improving renal outcomes: a metaanalysis. J Am Soc Nephrol 17(7):2006-2016

Scandinavian Simvastatin Survival Study Group (1994) Randomised trial of cholesterol lowering in 4444 patients with coronary heart disease: the Scandinavian Simvastatin Survival Study (4S). Lancet 344(8934):1383-1389

Schmidt S, Westhoff TH, Krauser P, Zidek W, van der Giet M (2008) The uraemic toxin phenylacetic acid increases the formation of reactive oxygen species in vascular smooth muscle cells. Nephrol Dial Transplant 23(1):65-71

Schuchardt M, Tolle M, Prufer J, van der Giet M (2011) Pharmacological relevance and potential of sphingosine 1-phosphate in the vascular system. Br J Pharmacol 163(6):1140-1162

Schwartz GG, Olsson AG, Ballantyne CM, Barter PJ, Holme IM, Kallend D, Leiter LA, Leitersdorf E, McMurray JJ, Shah PK, Tardif JC, Chaitman BR, Duttlinger-Maddux R, Mathieson J (2009) Rationale and design of the dal-OUTCOMES trial: efficacy and safety of dalcetrapib in patients with recent acute coronary syndrome. Am Heart J 158(6):896-901 e893 
Schwartz GG, Olsson AG, Abt M, Ballantyne CM, Barter PJ, Brumm J, Chaitman BR, Holme IM, Kallend D, Leiter LA, Leitersdorf E, McMurray JJ, Mundl H, Nicholls SJ, Shah PK, Tardif JC, Wright RS (2012) Effects of dalcetrapib in patients with a recent acute coronary syndrome. N Engl J Med 367(22):2089-2099

Sever PS, Dahlof B, Poulter NR, Wedel H, Beevers G, Caulfield M, Collins R, Kjeldsen SE, Kristinsson A, McInnes GT, Mehlsen J, Nieminen M, O’Brien E, Ostergren J (2003) Prevention of coronary and stroke events with atorvastatin in hypertensive patients who have average or lower-than-average cholesterol concentrations, in the Anglo-Scandinavian Cardiac Outcomes Trial--Lipid Lowering Arm (ASCOT-LLA): a multicentre randomised controlled trial. Lancet 361(9364):1149-1158

Shah AS, Tan L, Long JL, Davidson WS (2013) Proteomic diversity of high density lipoproteins: our emerging understanding of its importance in lipid transport and beyond. J Lipid Res 54 (10):2575-2585

Shoji T, Nishizawa Y, Nishitani H, Yamakawa M, Morii H (1992) Impaired metabolism of high density lipoprotein in uremic patients. Kidney Int 41(6):1653-1661

Sirpal S (2009) Myeloperoxidase-mediated lipoprotein carbamylation as a mechanistic pathway for atherosclerotic vascular disease. Clin Sci (Lond) 116(9):681-695

Sorrentino SA, Besler C, Rohrer L, Meyer M, Heinrich K, Bahlmann FH, Mueller M, Horvath T, Doerries C, Heinemann M, Flemmer S, Markowski A, Manes C, Bahr MJ, Haller H, von Eckardstein A, Drexler H, Landmesser U (2010) Endothelial-vasoprotective effects of highdensity lipoprotein are impaired in patients with type 2 diabetes mellitus but are improved after extended-release niacin therapy. Circulation 121(1):110-122

Speer T, Rohrer L, Blyszczuk P, Shroff R, Kuschnerus K, Krankel N, Kania G, Zewinger S, Akhmedov A, Shi Y, Martin T, Perisa D, Winnik S, Muller MF, Sester U, Wernicke G, Jung A, Gutteck U, Eriksson U, Geisel J, Deanfield J, von Eckardstein A, Luscher TF, Fliser D, Bahlmann FH, Landmesser U (2013) Abnormal high-density lipoprotein induces endothelial dysfunction via activation of Toll-like receptor-2. Immunity 38(4):754-768

Studer M, Briel M, Leimenstoll B, Glass TR, Bucher HC (2005) Effect of different antilipidemic agents and diets on mortality: a systematic review. Arch Intern Med 165(7):725-730

Sung CC, Hsu YC, Chen CC, Lin YF, Wu CC (2013) Oxidative stress and nucleic acid oxidation in patients with chronic kidney disease. Oxid Med Cell Longev 2013:301982

Svensson M, Schmidt EB, Jorgensen KA, Christensen JH (2006) N-3 fatty acids as secondary prevention against cardiovascular events in patients who undergo chronic hemodialysis: a randomized, placebo-controlled intervention trial. Clin J Am Soc Nephrol 1(4):780-786

The long-term intervention with pravastatin in ischaemic disease (LIPID) study group (1998) Prevention of cardiovascular events and death with pravastatin in patients with coronary heart disease and a broad range of initial cholesterol levels. N Engl J Med 339(19):1349-1357

Theilmeier G, Schmidt C, Herrmann J, Keul P, Schafers M, Herrgott I, Mersmann J, Larmann J, Hermann S, Stypmann J, Schober O, Hildebrand R, Schulz R, Heusch G, Haude M, von Wnuck LK, Herzog C, Schmitz M, Erbel R, Chun J, Levkau B (2006) High-density lipoproteins and their constituent, sphingosine-1-phosphate, directly protect the heart against ischemia/reperfusion injury in vivo via the S1P3 lysophospholipid receptor. Circulation 114(13):1403-1409

Thompson GR, Seed M (2013) Lipoprotein(a): the underestimated cardiovascular risk factor. Heart 100(7):534-535

Tolle M, Huang T, Schuchardt M, Jankowski V, Prufer N, Jankowski J, Tietge UJ, Zidek W, van der Giet M (2012) High-density lipoprotein loses its anti-inflammatory capacity by accumulation of pro-inflammatory-serum amyloid A. Cardiovasc Res 94(1):154-162

Tonelli M, Wanner C (2013) Lipid management in chronic kidney disease: synopsis of the kidney disease: improving global outcomes 2013 clinical practice guideline. Ann Intern Med 160 (3):182-189

Tonelli M, Collins D, Robins S, Bloomfield H, Curhan GC (2004) Gemfibrozil for secondary prevention of cardiovascular events in mild to moderate chronic renal insufficiency. Kidney Int 66(3):1123-1130 
Tonelli M, Wiebe N, Culleton B, House A, Rabbat C, Fok M, McAlister F, Garg AX (2006) Chronic kidney disease and mortality risk: a systematic review. J Am Soc Nephrol 17 (7):2034-2047

Tucker PS, Dalbo VJ, Han T, Kingsley MI (2013) Clinical and research markers of oxidative stress in chronic kidney disease. Biomarkers 18(2):103-115

Uhlar CM, Whitehead AS (1999) Serum amyloid A, the major vertebrate acute-phase reactant. Eur J Biochem 265(2):501-523

Undurti A, Huang Y, Lupica JA, Smith JD, DiDonato JA, Hazen SL (2009) Modification of high density lipoprotein by myeloperoxidase generates a pro-inflammatory particle. J Biol Chem 284(45):30825-30835

van Capelleveen JC, Brewer HB, Kastelein JJ, Hovingh GK (2014) Novel therapies focused on the high-density lipoprotein particle. Circ Res 114(1):193-204

van der Giet M, Tölle M, Pratico D, Lufft V, Schuchardt M, Hörl M, Zidek W, Tietge UF (2010a) Increased type IIA secretory phospholipase A2 expression contributes to oxidative stress in end-stage renal disease. J Mol Med 88(1):75-83

van der Giet M, Schuchardt M, Huang T, Prüfer N, Prüfer J, Tölle M (2010b) Dysfunctional HDL from patients with end-stage renal disease recover after successful renal transplantation. Am J Transplant 10(Abstract \#50):53

van der Westhuyzen DR, Cai L, de Beer MC, de Beer FC (2005) Serum amyloid A promotes cholesterol efflux mediated by scavenger receptor B-I. J Biol Chem 280(43):35890-35895

Van Lenten BJ, Hama SY, de Beer FC, Stafforini DM, McIntyre TM, Prescott SM, La Du BN, Fogelman AM, Navab M (1995) Anti-inflammatory HDL becomes pro-inflammatory during the acute phase response. Loss of protective effect of HDL against LDL oxidation in aortic wall cell cocultures. J Clin Invest 96(6):2758-2767

Vaziri ND (2006) Dyslipidemia of chronic renal failure: the nature, mechanisms, and potential consequences. Am J Physiol 290(2):F262-F272

Vaziri ND (2013) Role of dyslipidemia in impairment of energy metabolism, oxidative stress, inflammation and cardiovascular disease in chronic kidney disease. Clin Exp Nephrol 1-4

Vaziri ND, Norris K (2011) Lipid disorders and their relevance to outcomes in chronic kidney disease. Blood Purif 31(1-3):189-196

Vaziri ND, Deng G, Liang K (1999) Hepatic HDL receptor, SR-B1 and Apo A-I expression in chronic renal failure. Nephrol Dial Transplant 14(6):1462-1466

Vaziri ND, Moradi H, Pahl MV, Fogelman AM, Navab M (2009) In vitro stimulation of HDL antiinflammatory activity and inhibition of LDL pro-inflammatory activity in the plasma of patients with end-stage renal disease by an apoA-1 mimetic peptide. Kidney Int 76(4):437-444

Vaziri ND, Yuan J, Ni Z, Nicholas SB, Norris KC (2012) Lipoprotein lipase deficiency in chronic kidney disease is accompanied by down-regulation of endothelial GPIHBP1 expression. Clin Exp Nephrol 16(2):238-243

Vickers KC, Remaley AT (2014) HDL and cholesterol: life after the divorce? J Lipid Res 55 (1):4-12

Wang F, Zheng J, Ye P, Luo L, Bai Y, Xu R, Sheng L, Xiao T, Wu H (2013) Association of highdensity lipoprotein cholesterol with the estimated glomerular filtration rate in a communitybased population. PLoS ONE 8(11):e79738

Wanner C, Krane V, Marz W, Olschewski M, Mann JF, Ruf G, Ritz E (2005) Atorvastatin in patients with type 2 diabetes mellitus undergoing hemodialysis. N Engl J Med 353(3):238-248

Watson AD, Berliner JA, Hama SY, La Du BN, Faull KF, Fogelman AM, Navab M (1995) Protective effect of high density lipoprotein associated paraoxonase. Inhibition of the biological activity of minimally oxidized low density lipoprotein. J Clin Invest 96 (6):2882-2891

Watson CE, Weissbach N, Kjems L, Ayalasomayajula S, Zhang Y, Chang I, Navab M, Hama S, Hough G, Reddy ST, Soffer D, Rader DJ, Fogelman AM, Schecter A (2011) Treatment of patients with cardiovascular disease with L-4 F, an apo-A1 mimetic, did not improve select biomarkers of HDL function. J Lipid Res 52(2):361-373 
Weichhart T, Kopecky C, Kubicek M, Haidinger M, Doller D, Katholnig K, Suarna C, Eller P, Tolle M, Gerner C, Zlabinger GJ, van der Giet M, Horl WH, Stocker R, Saemann MD (2012) Serum amyloid A in uremic HDL promotes inflammation. J Am Soc Nephrol 23(5):934-947 Yamamoto S, Yancey PG, Ikizler TA, Jerome WG, Kaseda R, Cox B, Bian A, Shintani A, Fogo AB, Linton MF, Fazio S, Kon V (2012) Dysfunctional high-density lipoprotein in patients on chronic hemodialysis. J Am Coll Cardiol 60(23):2372-2379

Yeung CK, Shen DD, Thummel KE, Himmelfarb J (2013) Effects of chronic kidney disease and uremia on hepatic drug metabolism and transport. Kidney Int 85:522-528

Zheng L, Nukuna B, Brennan ML, Sun M, Goormastic M, Settle M, Schmitt D, Fu X, Thomson L, Fox PL, Ischiropoulos H, Smith JD, Kinter M, Hazen SL (2004) Apolipoprotein A-I is a selective target for myeloperoxidase-catalyzed oxidation and functional impairment in subjects with cardiovascular disease. J Clin Invest 114(4):529-541

Zimmermann J, Herrlinger S, Pruy A, Metzger T, Wanner C (1999) Inflammation enhances cardiovascular risk and mortality in hemodialysis patients. Kidney Int 55(2):648-658

Zuo Y, Yancey P, Castro I, Khan WN, Motojima M, Ichikawa I, Fogo AB, Linton MF, Fazio S, Kon V (2009) Renal dysfunction potentiates foam cell formation by repressing ABCA1. Arterioscler Thromb Vasc Biol 29(9):1277-1282 